\title{
Exploring Chemical Diversity of Phorbas Sponges as a Source of Novel Lead Compounds in Drug Discovery
}

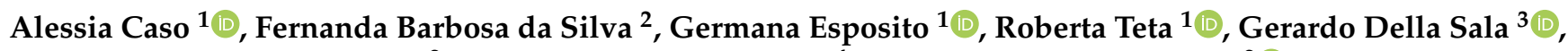 \\ Laura P. A. Nunes Cavalcanti ${ }^{2}$, Alessandra Leda Valverde ${ }^{4}$, Roberto Carlos C. Martins ${ }^{2}$ (D) \\ and Valeria Costantino ${ }^{1, *(\mathbb{D})}$
}

1 Department of Pharmacy, University of Naples Federico II, Via D. Montesano, 49, 80131 Naples, Italy; alessia.caso@unina.it (A.C.); germana.esposito@unina.it (G.E.); roberta.teta@unina.it (R.T.)

2 Instituto de Química de Produtos Naturais Walter Mors, Universidade Federal do Rio de Janeiro, Av. Carlos Chagas Filho, 373, Rio de Janeiro 21941-599, Brazil; silvanandab@gmail.com (F.B.d.S.); laurapatricionunes@gmail.com (L.P.A.N.C.); roberto.rcc@gmail.com (R.C.C.M.)

3 Department of Marine Biotechnology, Stazione Zoologica Anton Dohrn, Villa Comunale, 80125 Naples, Italy; gerardo.dellasala@szn.it

4 Departamento de Química Orgânica, Instituto de Química, Universidade Federal Fluminense, Outeiro de São João Batista s/n, Niterói, Rio de Janeiro 24020-141, Brazil; alessandravalverde@id.uff.br

* Correspondence: valeria.costantino@unina.it

check for updates

Citation: Caso, A.; da Silva, F.B.; Esposito, G.; Teta, R.; Sala, G.D.; Cavalcanti, L.P.A.N.; Valverde, A.L.; Martins, R.C.C.; Costantino, V. Exploring Chemical Diversity of Phorbas Sponges as a Source of Novel Lead Compounds in Drug Discovery. Mar. Drugs 2021, 19, 667. https:// doi.org/10.3390/md19120667

Academic Editor: Bill J. Baker

Received: 24 October 2021

Accepted: 23 November 2021

Published: 26 November 2021

Publisher's Note: MDPI stays neutral with regard to jurisdictional claims in published maps and institutional affiliations.

Copyright: (c) 2021 by the authors. Licensee MDPI, Basel, Switzerland. This article is an open access article distributed under the terms and conditions of the Creative Commons Attribution (CC BY) license (https:/ / creativecommons.org/licenses/by/ $4.0 /)$.

\begin{abstract}
Porifera, commonly referred to as marine sponges, are acknowledged as major producers of marine natural products (MNPs). Sponges of the genus Phorbas have attracted much attention over the years. They are widespread in all continents, and several structurally unique compounds have been identified from this species. Terpenes, mainly sesterterpenoids, are the major secondary metabolites isolated from Phorbas species, even though several alkaloids and steroids have also been reported. Many of these compounds have presented interesting biological activities. Particularly, Phorbas sponges have been demonstrated to be a source of cytotoxic metabolites. In addition, MNPs exhibiting cytostatic, antimicrobial, and anti-inflammatory activities have been isolated and structurally characterized. This review provides an overview of almost 130 secondary metabolites from Phorbas sponges and their biological activities, and it covers the literature since the first study published in 1993 until November 2021, including approximately 60 records. The synthetic routes to the most interesting compounds are briefly outlined.
\end{abstract}

Keywords: Phorbas; marine sponges; marine natural products (MNPs); alkaloids; terpenoids; macrolides; cytotoxic metabolites; antimicrobial and anti-inflammatory activities

\section{Introduction}

Biodiversity of marine organisms that reflects on their rich chemical diversity is an important source of novel drug-lead skeletons. Sponges, among other organisms, are one of the main sources of novel skeletons as well as of lead compounds [1,2], promising remedies in drug discovery [3,4] and biotechnological applications. Even if the origin of sponge-derived compounds is still under debate, a growing body of evidence suggests that many marine natural products (MNPs) are produced by microorganisms associated with the sponge [5,6]. In fact, multicellular organisms, such as sponges, are now defined as "holobionts", i.e., an association between the host and its microorganism community. Therefore, studies performed on sponge organic extracts are actually categorized as studies on holobiont organic extracts [7]. One of the most common classes of sponge-symbionts is cyanobacteria, known as the real producer of some classes of secondary metabolites, specially cyanotoxins [8-10].

Chemical diversity coming from marine sponges may still drive drug discovery research [11-13]. The genus Phorbas is a suitable example to illustrate this point. Phorbasderived natural products discovered so far include compounds belonging to four main 
classes: alkaloids, macrolides, steroids, and terpenoids. Many of them possess unique structures that might play an important role in biotechnological and pharmaceutical applications.

The genus Phorbas belongs to the class Demospongiae, order Poecilosclerida, family Hymedesmiidae [14], and is the most representative among the 10 accepted genera, which also includes Hamigera, Acanthancora, and Hemimycale [15-18]. Phorbas stands out not only in the number of isolated MNPs, but also in the large number of bioactive compounds, mainly displaying cytotoxic activity [19]. These sponges are widespread and are present on all continents, including Antarctica (Figure 1) [20].

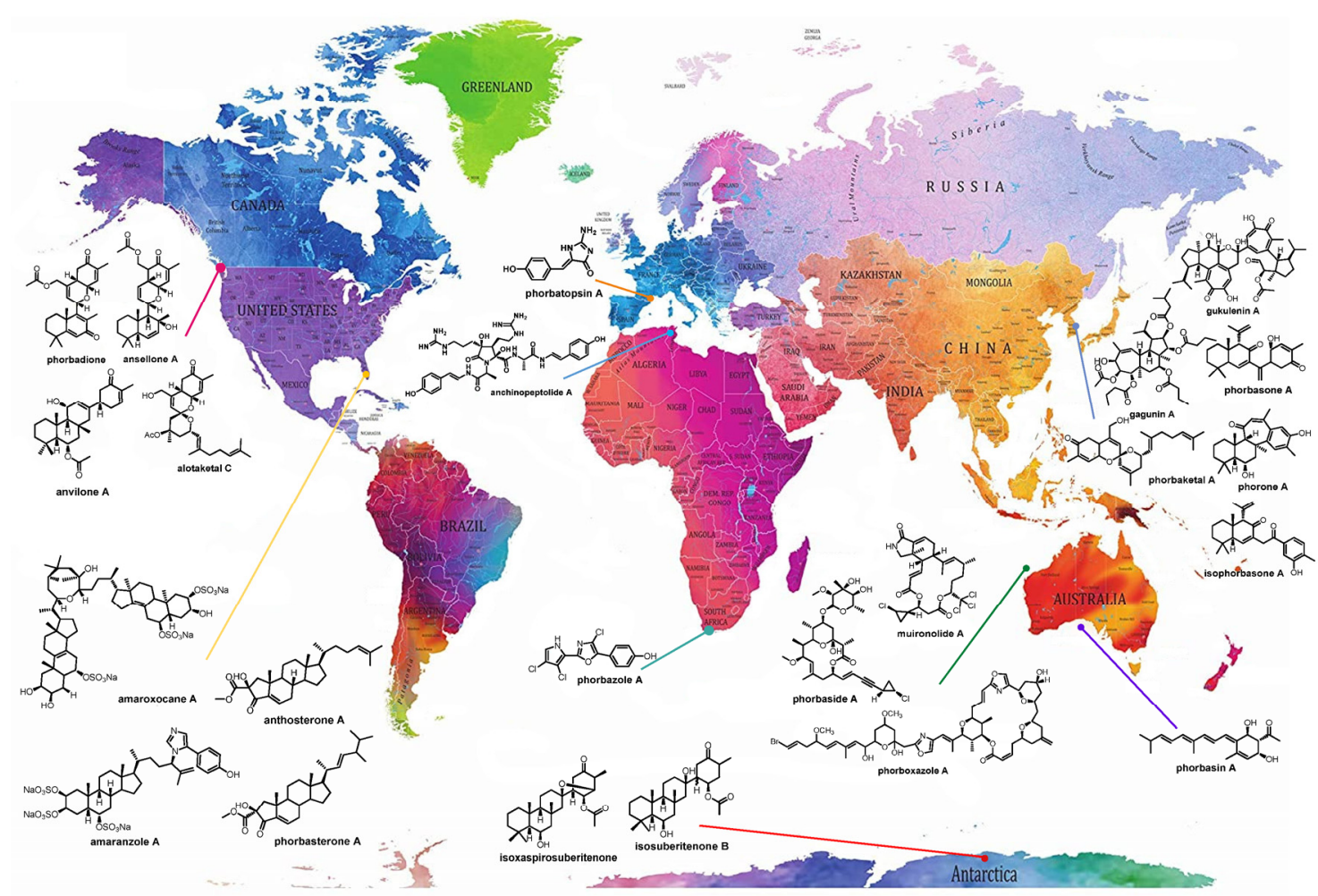

Figure 1. Global distribution of sponges of the genus Phorbas and their bioactive metabolites, allowing visualization of the wide distribution of sponges of this genus across all continents, even in the presence of different biotic and abiotic factors. Many metabolites of the same class are found in species collected from different locations. Original world map image source: https:/ / www.amazon.it/Stylish-Living-Mappamondo-Planisfero-Decorazione/dp/B07N1NNPD8 (accessed on 25 February 2021).

The first study was carried out by Casapullo et al. in 1993, reporting on the structural elucidation of four dimeric peptide alkaloids, known as anchinopeptolides [21,22], from a sample of Phorbas tenacior collected along the Tunisian coast. The following year, Rudi et al. (1994) analyzed a sample from South Africa and highlighted, for the first time, the oxazole moiety as an uncommon feature of secondary metabolites from marine sponges [23]. This chemical feature is a distinctive marker of this species, as it is part of phorboxazoles and macrolides, isolated by Searle and Molinski (1995), from a sample collected in Western Australia [24], and of their minor analogue, hemi-phorboxazole A [25]. Secondary metabolites belonging to the alkaloid class have been also isolated from a sample collected along the coast of Marseille, France, and studied by the Bourguet's group. With this regard, phorbatopsins are alkaloids with a benzylidene 2-aminoimidazolones structure [26]. Finally, the alkaloid-moiety was also present in the structure of a series of imidazolyl steroids, i.e., amaranzoles, isolated from a sample collected in the shallow coral reef water of Key Largo, Florida [27,28].

Nitrogen incorporation seems to be a feature of the Phorbas sponge holobiome. Nitrogen is also found in some MNPs belonging to the class of terpenes. Indeed, the taurine 
unit, not very common in MNPs from sponges, has been found as a part of the terpenes gukulenin E and phorbasins D-G [29-31].

This review considers the potential of sponges of the genus Phorbas as sources of natural products, and summarizes what is known about their bioactivities. Secondary metabolites belonging to the above-mentioned four classes have been evaluated mainly for cytotoxic activity. However, sponges of the genus Phorbas have also been reported as a source of compounds presenting promising antimicrobial, antioxidant, and isocitrate lyase (ICL) inhibition activities [14]. This work provides an overview of the literature records upon Phorbas secondary metabolites and their biological activities, starting with the first study published in 1993 until November 2021.

\section{Chemistry}

\subsection{Alkaloids}

\subsubsection{Anchinopeptolides}

Anchinopeptolide A (1) is a dimeric peptide alkaloid isolated from Phorbas tenacior (previously Anchinoe tenacior) and collected in Tunisia. This is the first report about Phorbas, which was published in 1993 [21]. Following this work, Casapullo et al. (1994) described four closely related compounds from the same sponge, the anchinopeptolides B-D (2-4) and cycloanchinopeptolide C (6), formed by an intramolecular cycloaddition of anchinopeptolide C (3) [22]. Compound 6 was not detected in the sponge extract but could be synthesized by a photoinduced intramolecular [2+2] cycloaddition. This evidence strongly supports the hypothesis of its artefactual origin [32]. Silva et al. (2019) isolated anchinopeptolide E (5), the epimer at C-5' of compound 3 (Figure 2), from a specimen of $P$. tenacior collected in France.

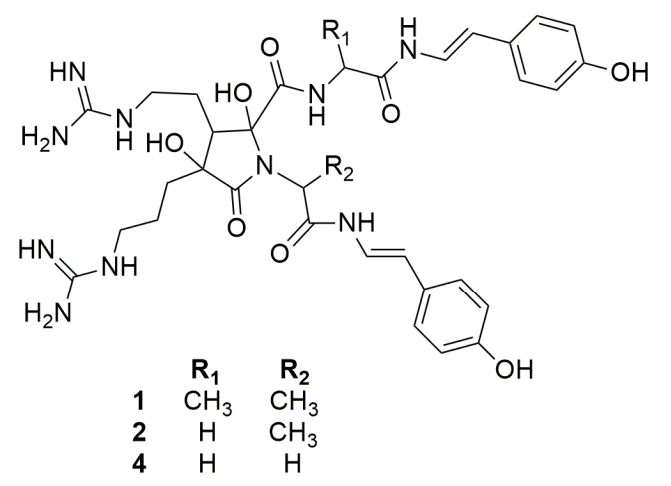<smiles>CC(NC(=O)C1(O)C(CCNC(=N)N)C(O)(CCCNC(=N)N)C(=O)N1CC(=O)N/C=C/c1ccc(O)cc1)C(=O)N/C=C/c1ccc(O)cc1</smiles><smiles>C[C@H](NC(=O)[C@H]1[C@H](CCNC(=N)N)[C@@H](O)C(=O)N1CC(=O)N/C=C/c1ccc(O)cc1)C(=O)N/C=C/c1ccc(O)cc1</smiles><smiles>CC(NC(=O)C1NC(=O)C1NC(=O)CN1C(=O)C(O)(CCCNC(=N)N)C(CCNC(=N)N)C1(O)C(=O)NC1C(c2ccc(O)cc2)C(c2ccc(O)cc2)C1c1ccc(O)cc1)C(N)=O</smiles>

Figure 2. Chemical structures of Anchinopeptolides A-E (1-5) and Cicloanchinopeptolide C (6).

Further studies on $P$. tenacior allowed the identification of two compounds, i.e., 6-(p-hydroxyphenyl)-2H-3,4-dihydro-1,1-dioxo-1,4-thiazine (7) and l-glu-gly-4-hydroxystirylamine (8) (Figure 3) [33]. 
<smiles>O=S1(=O)CCNC=C1c1ccc(O)cc1</smiles><smiles>NC(CCC(=O)O)C(=O)NCC(=O)N/C=C/c1ccc(O)cc1</smiles>

Figure 3. Chemical structures of compounds 7 and 8.

\subsubsection{Phorbazoles}

The pioneering work of Rudi et al. (1994) allowed the first isolation of phorbazoles A-D (9-12) (Figure 4). They represent a new class of marine alkaloids embodying the chlorinated pyrrole moiety. Phorbazoles, isolated in small amounts from a sample collected in South Africa, differ themselves only by the presence and/or position of the chlorine atoms, and their structures were elucidated using mono- and bi-dimensional NMR data coupled with X-ray diffraction studies [34].<smiles>[R4]c1nc(-c2[nH]c([R])c([R])c2[R3])oc1-c1ccc(O)cc1</smiles>

$\begin{array}{lllll} & \mathbf{R}_{\mathbf{1}} & \mathbf{R}_{\mathbf{2}} & \mathbf{R}_{\mathbf{3}} & \mathbf{R}_{\mathbf{4}} \\ \mathbf{9} & \mathrm{H} & \mathrm{Cl} & \mathrm{Cl} & \mathrm{Cl} \\ \mathbf{1 0} & \mathrm{Cl} & \mathrm{Cl} & \mathrm{Cl} & \mathrm{H} \\ \mathbf{1 1} & \mathrm{H} & \mathrm{Cl} & \mathrm{Cl} & \mathrm{H} \\ \mathbf{1 2} & \mathrm{H} & \mathrm{H} & \mathrm{Cl} & \mathrm{H}\end{array}$

Figure 4. Chemical structures of Phorbazoles A-D (9-12).

In 2020, the total synthesis of the trichlorinated phorbazole B (10) has been realized in six steps (overall yield of 23\%) using an oxazole as precursor and late stage electrophilic chlorination as key mechanism [35], while a synthesis of phorbazole C was reported in 2001 and relied on pyrrole as a precursor [36].

\subsubsection{Zarzissine}

Among the pioneering works, the study of Bouaicha et al. allowed the isolation of zarzissine (13), a pyridazine derivative (Figure 5). This small, highly nitrogenated alkaloid was isolated from a P. paupertas (previously Anchinoe paupertas and P. paupertas) specimen, collected in the Mediterranean Sea, Tunisia, through Sephadex LH-20 column chromatography and preparative HPLC, being unequivocally characterized by GC-MS and NMR analysis [37]. Vacelet and Pérez revised the taxonomy of P. paupertas, and the name Phorbas topsenti was proposed in 2008 [38].<smiles>Nc1nc2cnncc2[nH]1</smiles>

13

Figure 5. Chemical structure of Zarzissine (13).

\subsubsection{Phorbatopsins}

Phorbatopsins A-C (14-16) were isolated from P. topsenti collected off Marseille at a depth of $5 \mathrm{~m}$, displaying an unprecedented 2-aminoimidazole core (Figure 6). The structure of phorbatopsins was easily elucidated through MS and mono- and bidimensional NMR 
analysis. The absolute configuration at C-6 of phorbatopsin B (15) was determined by using a modified procedure of Mosher's method [26].<smiles>NC1=NC(=O)C(=Cc2ccc(O)cc2)N1</smiles>

14<smiles>NC1=NC(=O)[C@H]([C@H](O)c2ccc(O)cc2)N1</smiles>

15<smiles>NC1=NC(=O)C(Cc2ccc(O)cc2)N1</smiles>

16

Figure 6. Chemical structures of Phorbatopsins A-C (14-16).

Phorbatopsins only differ in the degree of oxidation at C-6. Carbonyl or hydroxyl groups are known for their affinity for free radicals, and the double bond seems to be essential for good antioxidant activity. Biological data perfectly reflect this observation, since compound $\mathbf{1 4}$ showed the best activity as a radical scavenger in the ORAC assays, followed by compounds $\mathbf{1 5}$ and $\mathbf{1 6}$, that lack both the double bond and the hydroxyl group at position $6[26]$.

\subsection{Macrolides}

\subsubsection{Phorboxazoles}

In 1995, Searle and Molinski [24] reported, for the first time the isolation of two phenyl-pyrrolyloxazoles, phorboxazoles A-B (17-18) (Figure 7), from a sample collected in western Australia. These compounds belong to the macrolide class containing seven rings, including two oxazoles and four oxane rings, and represent the first members of a novel class of macrolides. Determination of conformation and relative configurations was not an easy task because of the fifteen stereogenic centers and seven rings present in their structure. Nevertheless, this is a didactic example showing how conformation and relative configuration assignment in large macrolide-rings is feasible, providing that some constraints are imposed, such as those due to the presence of oxane and oxazole rings along the macrolide's perimeter [39].

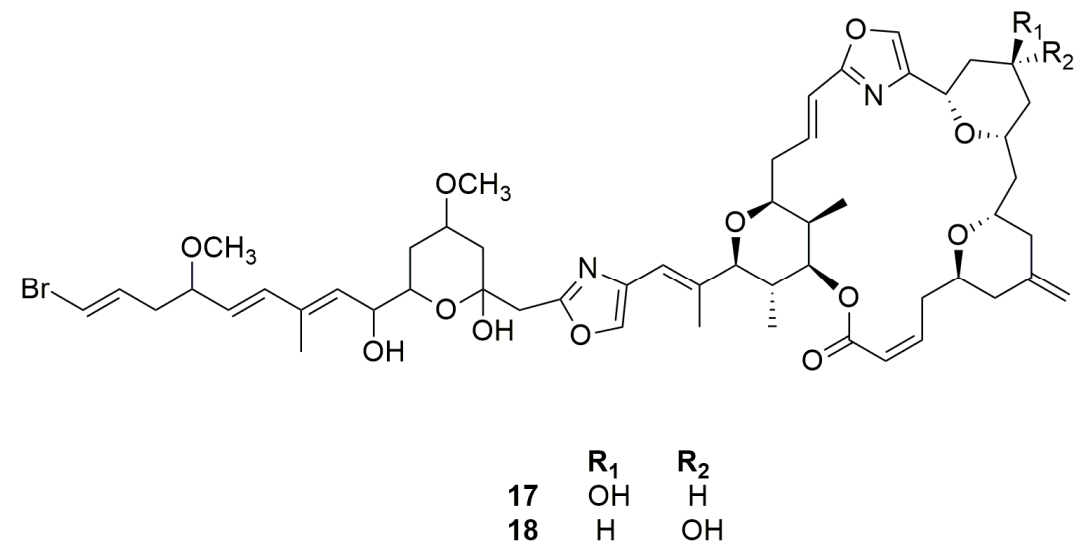

Figure 7. Chemical structures of Phorboxazoles A and B (17-18).

\subsubsection{Muironolides}

One more example of the incredible Phorbas chemodiversity is the isolation of muironolide A (19), a novel macrolide, bearing two unprecedented structural features: an hexahydro$1 \mathrm{H}$-isoindolone-triketide ring and a trichlorocarbinol ester (Figure 8) [40]. 


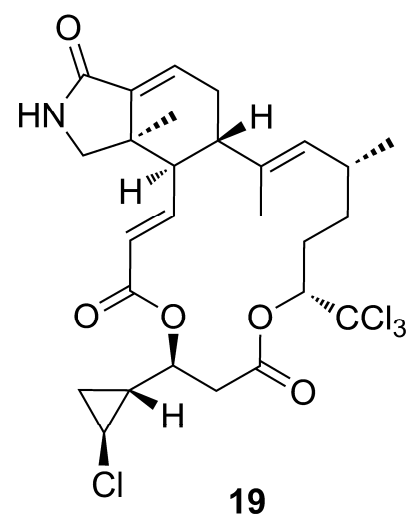

Figure 8. Chemical structure of muironolide A (19).

Muironolide A (19) contains a cyclopropane ring, a structural motif already found in phorbasides. Interestingly, the configuration of the cyclopropane ring is opposite compared to phorbaside A (20), but the same as that of callipeltoside A, a cytotoxic glycoside macrolide isolated by Zampella et al. (1996) from the new Caledonian sponge Callipelta sp. [41].

The absolute configuration of the macrolide ring has been determined by CD spectroscopy, while the assignment of the absolute stereochemistry of the cyclopropane ring is a nice example of microscale degradation as a useful tool for natural product elucidation, when other powerful methods, such as NMR NOE data and J-based assignments, fail $[42,43]$. Molinski's group succeeded in the microscale degradation of muironolide A (19) with basic hydrolysis to achieve the cyclopropane-unit derivative (Scheme 1).

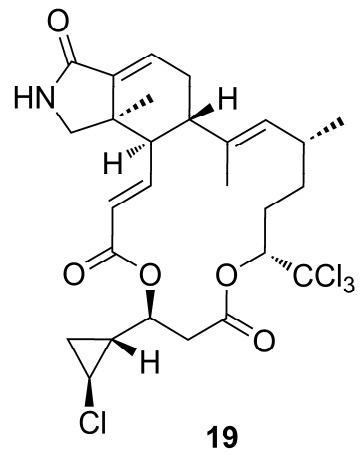<smiles>[R]OCCC(O)C1CC1Cl</smiles>

$(3 S, 4 S, 5 R)-19 b$

Scheme 1. Microscale degradation of Muironolide A (19).

The four possible stereoisomers were synthesized, starting from (-)-O-menthyl acrylate (Scheme 2), and used as standards to assign the stereochemistry of the cyclopropane unit of muironolide A (19) by comparison of their retention times using chiral LC-MS.

\subsubsection{Phorbasides}

Phorbasides (20-28) are glycosylated macrolides possessing a unique structural motif: an ene-yne-trans-2-chlorocyclopropane moiety. They contain the same macrolide ring but different sugar units (Figure 9). Particularly, in phorbaside D (23), the sugar unit is fused with an oxazolone unit, while phorbaside B (21) and C (22) have a 1,4-linked disaccharide made of L-evalose [44,45].

Phorbasides A-E (20-24), isolated from a Phorbas specimen collected off the Western Australian coastline, which also provided phorboxazoles A-B (17-18), showed different cytotoxicity, which seems to be dependent upon the presence of a free hydroxyl group at position $2^{\prime}$ or $2^{\prime}$ [44]. The repurification of minor fractions from the same sponge extract yielded phorbaside F (25) [46], only differing from phorbaside A (20) by the absence of a methyl group on the eastern side of the macrolide ring. Phorbaside G (26) is the only 
member of phorbasides family containing a C-4 oxidized pyranoside, while phorbaside I (28) is characterized by the presence of a formamide group instead of a hydroxyl group on the pyranoside unit (Figure 9) [47].<smiles>C=CC(=O)OC1CC(C)CCC1C(=O)O</smiles><smiles>CC1CC[C@H](OC(=O)C2CC2(Cl)Cl)C(Cl)C1</smiles>

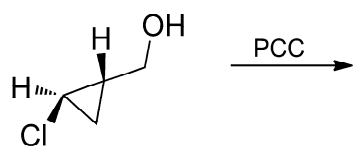

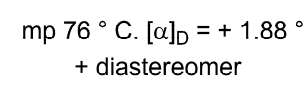

$(+)-(1 R, 2 S)$

+ diastereomer $86 \%$ ee<smiles>O=C(OCC#CC1CC1C(=O)O)C1CC1Cl</smiles>

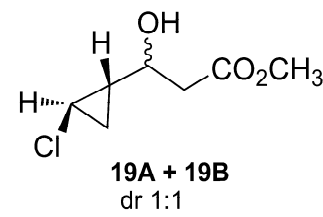

1) $\mathrm{LiOH}, \mathrm{THF}-\mathrm{H}_{2} \mathrm{O}$

$\underset{\text { HPLC, Chiralpak AD }}{\longrightarrow}$<smiles>O=C(O)CC(O)C1C[C@H]1Cl</smiles>

$(3 R, 4 S, 5 R)-19 \mathbf{a}$<smiles>[R]OC(=O)CC(O)[C@H]1C[C@H]1Cl</smiles>

$(3 S, 4 S, 5 R)-19 \mathbf{b}$<smiles>[R]OC(=O)CC(O)[C@H]1C[C@H]1Cl</smiles>

$(3 S, 4 R, 5 S)-19 \mathrm{c}$<smiles>[R]OC(=O)C[C@@H](O)[C@H]1C[C@H]1Cl</smiles>

$(3 R, 4 R, 5 S)-19 d$

Scheme 2. Degradation of (-)-O-menthyl acrylate afforded compounds 19a-d, used as standards for the establishment of the absolute stereochemistry of Muironolide A (19).

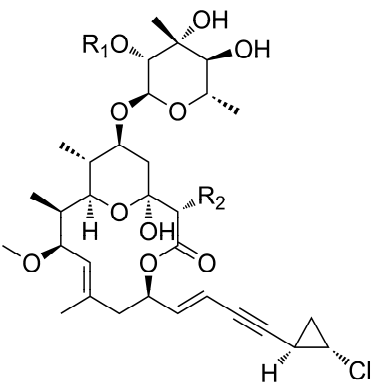
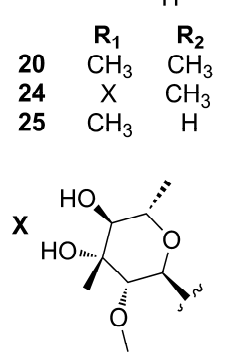
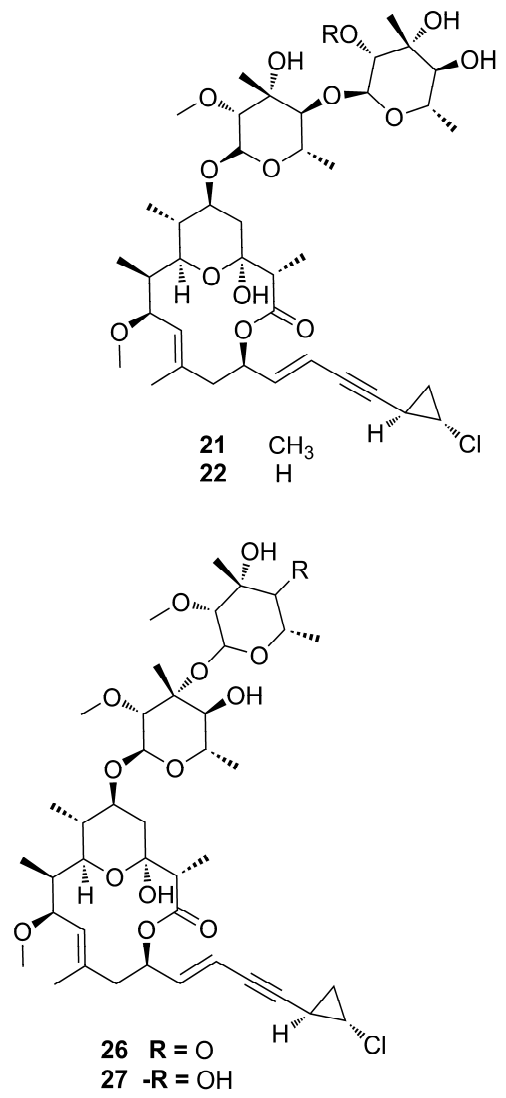

Figure 9. Chemical structures of Phorbasides A-I (20-28).
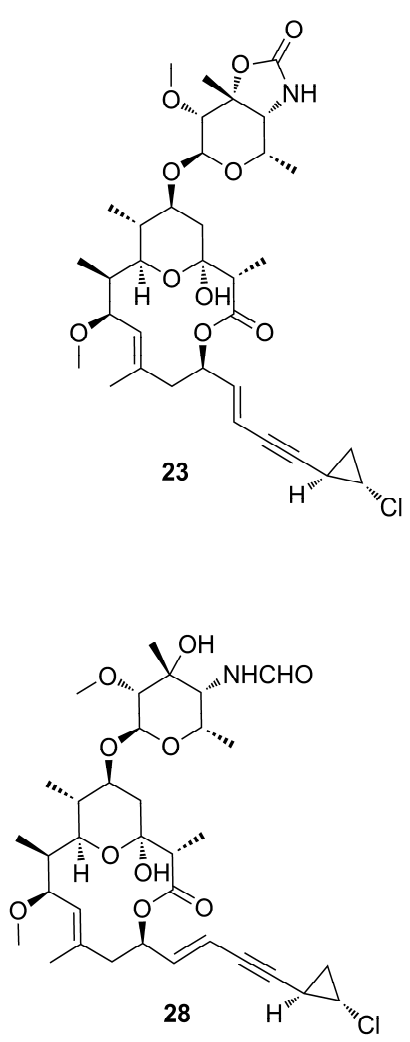


\subsection{Steroids}

\subsubsection{Phorbasterones}

Mazuno et al. reported, for the first time, the steroids phorbasterones A-D (29-34) from Phorbas amaranthus, collected in Florida [48]. These structures share a characteristic ring A-contracted steroid nucleus and differ from each other by the side chain: phorbasterone $\mathrm{A}$ (29) possesses a double bond at C-22 and a methyl group at C-24, phorbasterone B (30) has a fully saturated isoprenyl side chain, phorbasterone $\mathrm{Ca}$ and $\mathrm{Cb}(31-32)$ keep the double bond at C-22 and bear an ethyl group with opposite configuration at C-24, and finally, phorbasterone $\mathrm{Da}$ and $\mathrm{Db}$ (33-34) lack the double bond at C-22 but keep the ethyl group at C-24 (Figure 10).

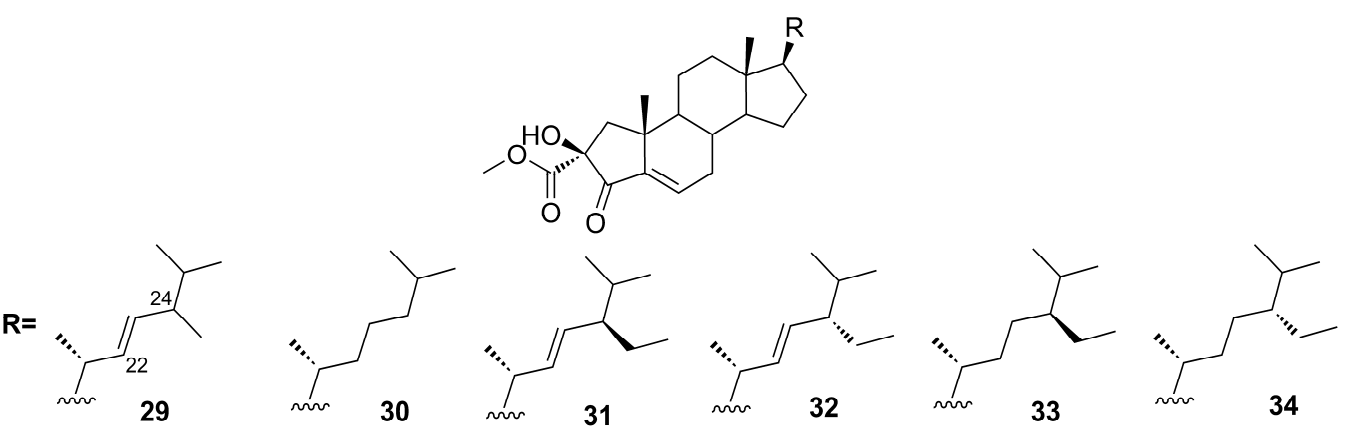

Figure 10. Chemical structures of Phorbasterones A (29), B (30), Ca (31), Cb (32), Da (33), and Db (34).

\subsubsection{Anthosterones}

Although anthosterones A-B (35-36) have been isolated from Anthoarcuata graceae by Tishler et al. (1988) for the first time [49], they were also isolated later from the organic extract of Phorbas amaranthus by Masuno et al. (2004), along with their congeners phorbasterones A-D (29-34) [48]. Anthosterones A-B (35-36) (Figure 11) represented the first examples of ring A-contracted steroids displaying a one-carbon appendage at C-2 of the cyclopentane ring. The difference between the compounds resides in the side chain: anthosterone A (35) possesses a double bond at C-24 as part of the side chain while anthosterone $\mathrm{B}$ (36) has an additional olefinic methylene at C-24.

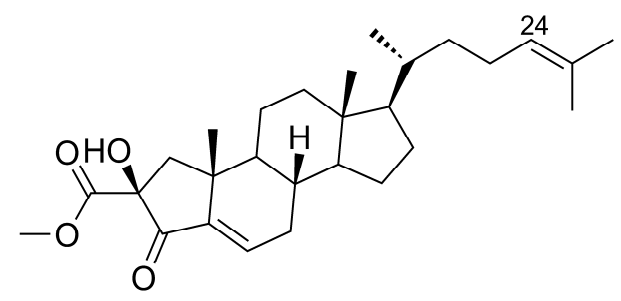

35

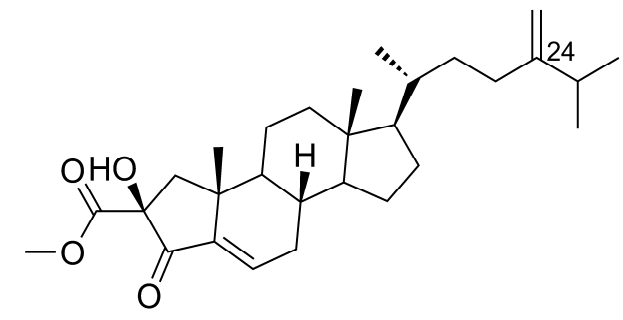

36

Figure 11. Chemical structures of Anthosterones A-B (35-36).

\subsubsection{Amaroxocanes}

Morinaka et al. (2009) reported amaroxocanes A and B (37-38), two dimeric sulfated steroids isolated from Phorbas amaranthus collected on shallow coral reefs off Key Largo, Florida [50]. According to Nahar and Sarker (2012), these compounds are characterized by two steroid moieties connected through an oxocane bridge (Figure 12), whose origin comes from different oxidative fusions of the side chains [51]. 


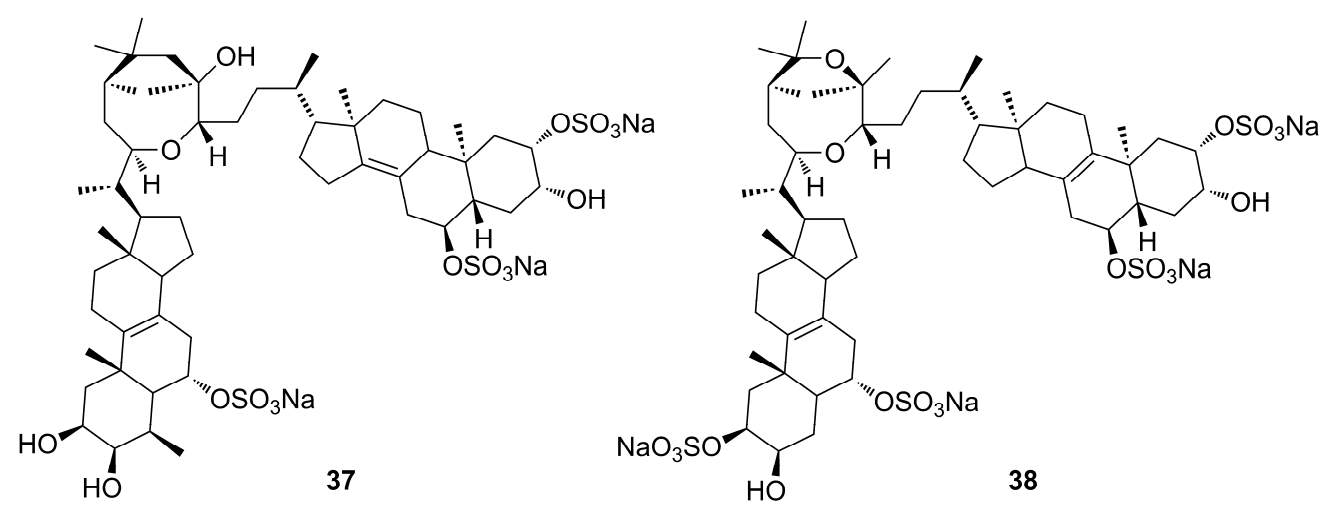

Figure 12. Chemical structures of Amaroxocanes A-B (37-38).

\subsubsection{Amaranzoles}

Amaranzole A (39) is the first imidazolyl steroidal alkaloid isolated from the tropical sponge Phorbas amaranthus, collected in Florida [27]. Extensive studies on the polar extracts of $P$. amaranthus led to the isolation, in 2010, of five additional steroidal alkaloids, amaranzoles B-F (40-44) [28]. Spectroscopic analysis allowed the structural elucidation of this family of compounds, with the main structural difference consisting of the replacement of the C24-N-(4-p-hydroxyphenyl)imidazol-5-yl function with a C24-O-(4-phydroxyphenyl)imidazole-2- carboxylate motif (Figure 13).

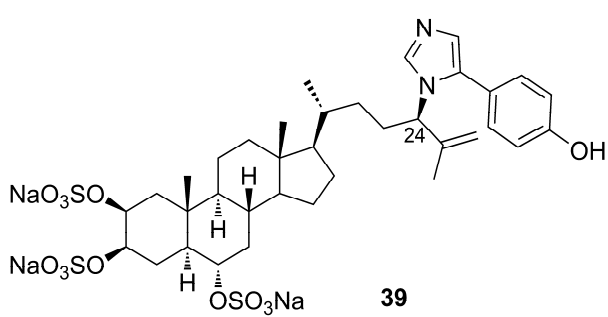

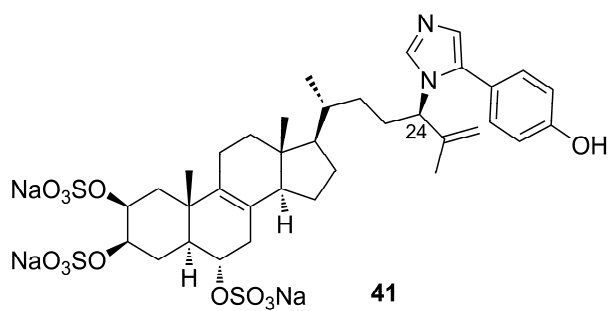

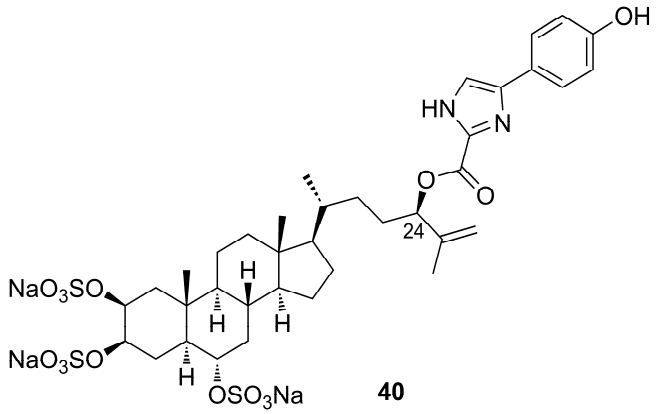

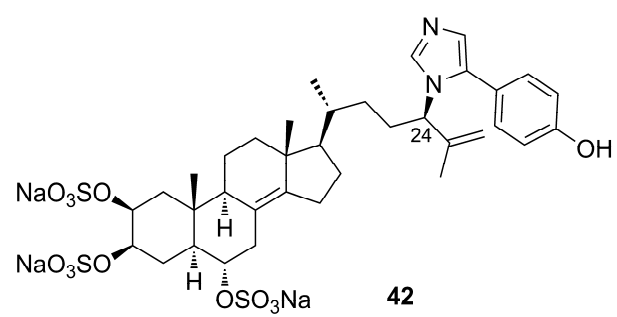

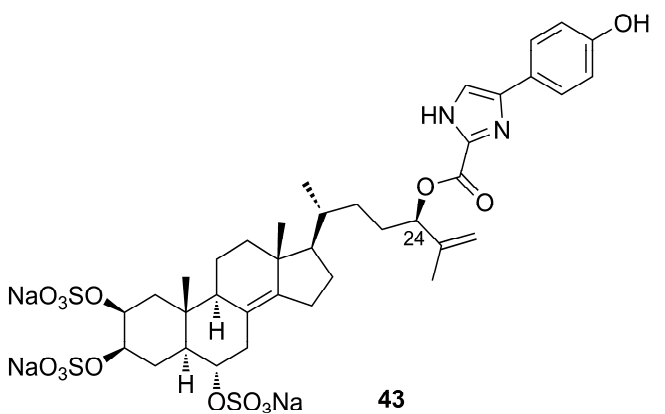

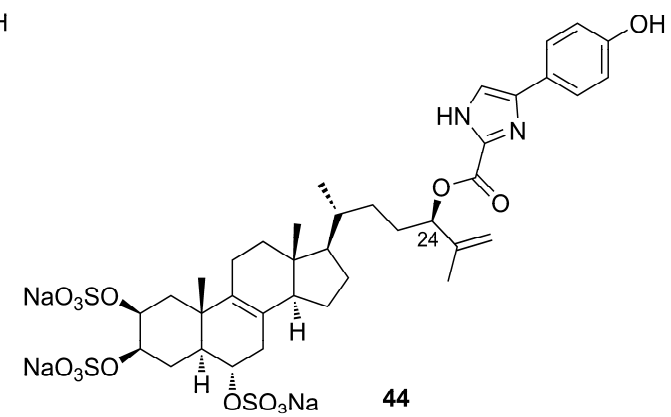

Figure 13. Chemical structures of Amaranzoles A-F (39-44).

The authors suggest that the main structural difference in the amaranzole family may be due to an allylic rearrangement that interchange C-24- $\mathrm{N}$ and C-24-O bonds with 
concomitant loss of $\mathrm{CO}_{2}$. The absolute configuration of the side chain at $\mathrm{C}-24$ was assigned through the synthesis of a model ester and the chiroptical comparison of its $C D$ spectrum with that of an amaranzole B (40) derivative [28].

\subsection{Terpenoids}

\subsubsection{Sesterterpenoids}

Phorbaketals

In search of bioactive compounds from sponges of the genus Phorbas collected in South Korea, Rho et al. (2009) identified a new type of tricyclic sesterterpenoids, phorbaketals A-C (45-47) (Figure 14), unprecedented in natural products [52]. They have a unique structure, with a spiroketal ring containing a hydrobenzopyran moiety. Phorbaketal A (45) has a carbonyl function at C-5, while phorbaketals B (46) and C (47) both possess a hydroxyl group in ring $\mathrm{A}$ at $\mathrm{C}-5$, but with opposite configuration. The absolute configuration of 45 was determined by chemical conversion. Phorbaketal B (46) and C (47) are diastereomers and probably originate from a reductive process of phorbaketal A (45). Compound 45 has been isolated in large amounts, raising the question of whether its real producer could be a symbiont organism of the sponge. To confirm this hypothesis, the mixed microbial cultures obtained from the homogenized sponge were further cultivated and then reextracted. As expected, phorbaketal A (45) was identified and isolated from the extract of the mixed bacteria culture. This allowed Rho and coworkers to suppose that compound $\mathbf{4 5}$ is produced by a symbiotic microorganism [52].<smiles></smiles>

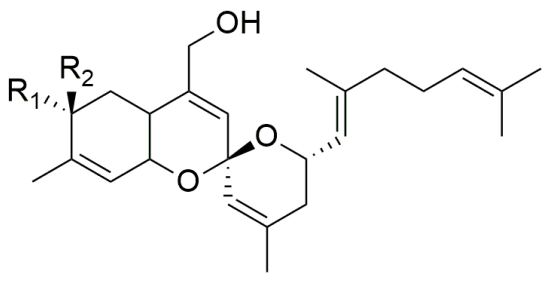<smiles>[R]C(O)O[14CH]=[14CH]</smiles>

Figure 14. Chemical structures of Phorbaketals A-C (45-47).

Some years later, three additional members of this family, phorbaketals L-N (48-50), were elucidated by HRFABMS and NMR analysis from a specimen of Phorbas sp. collected in South Korea [53]. Phorbaketals L-N (48-50) share the tricyclic moiety with the carbonyl group at C-5 with phorbaketal A (45), but differ in the side chain at C-16 (Figure 15). While phorbaketal A (45) has a double bond at C-17 (Figure 14), phorbaketal L (48) differs for the position of this double bond (which is present between C-18/C-19) and for the presence of a hydroxyl group at C-17. Contrariwise, phorbaketal M (54) keeps the double bond at C-17 but shows the presence of a hydroperoxide group at C-22 and a double bond at C-23/C-25. Finally, phorbaketal N (50) shares the double bond at C-18/C-19 with compound 48 but possesses a bromine instead of a hydroxyl group at C-17; moreover, it possesses an epoxide ring at $\mathrm{C}-22 / \mathrm{C}-23$.

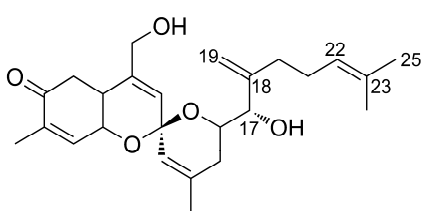

48

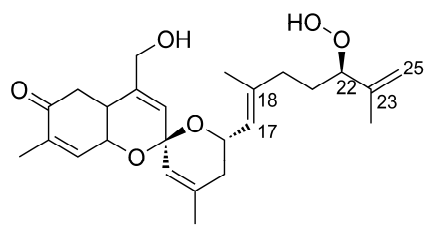

49<smiles>C=C(CCC1OC1(C)C)[C@H](Br)CC(C)=CC12CC1OC1C=C(C)C(=O)CC1C(CO)=CO2</smiles>

50

Figure 15. Chemical structure of Phorbaketals L-N (48-50). 
Circular dichroism (CD) analysis defined the absolute stereochemistry, suggesting that phorbaketals L-N (48-50) possess the same absolute configurations as phorbaketal A (45).

Wang et al. (2013) isolated eight new sesterterpenoids, namely phorbaketals D-K (51-58), from the organic extract of the Korean marine sponge Monanchora sp., along with their progenitors phorbaketals A-C (45-47), and phorbin A (59), a possible precursor of these sesterterpenoids (Figure 16) [54]. These compounds have not yet been identified in sponges of the genus Phorbas.<smiles>[R16][R16](O)O</smiles><smiles>[R]C1C[C@H]2C(C)=C[C@]3(C=C(C)C[C@H](/C=C(/C)CCC=C(C)C)O3)O[C@@H]2C=C1C</smiles><smiles>CC(=O)O[C@H]1C[C@@H]2C(CO)=C[C@]3(C=C(C)C[C@H](/C=C(\C)C/C=C/C(C)(C)O)O3)O[C@@H]2C=C1C</smiles>

$53(R)-\mathrm{OAC}$ $54(S)-O A C$<smiles>C=C(C[C@@H](O)/C=C(\C)CC/C=C(\C)CCC=C(C)C)[C@H]1CC(=O)C(C)=C[Z20]1O</smiles>

59

Figure 16. Chemical structures of Phorbaketals D-K (51-58) and phorbin A (59) isolated from sponge Monanchora sp.

Alotaketals

Aloketals are sesterterpenoids with an unprecedented alotane carbon skeleton. Aloketal A (60) and B (61) (Figure 17) were isolated from the extracts of the sponge Hamigera sp., collected in Papua New Guinea [55]. They are the first members of a family of sesterterpenoids that may have the same "alotane" precursor, like other compounds identified in Phorbas, such as phorbaketals (45-47) and suberitonones (80-85). Alotane sesterterpenoids have been isolated from sponges collected in three widely separated locations around the Pacific Rim (Papua New Guinea, Korea, and British Columbia). Alotaketal C (62) was isolated by Daoust et al. (2013) from a specimen of Phorbas collected in British Columbia (Figure 17) [56].

Further studies aimed at an exhaustive search for minor sesterterpenoid compounds in the same Phorbas extract yielding alotaketal C (62) allowed the identification of alotaketals D (63) and E (64) (Figure 17) [57].

The basic skeleton of alotaketals is a tricyclic structure, very similar to phorbaketals (45-58). Alotaketals possess a carbonyl group at C-4 in ring A, except for alotaketal D (63), in which the carbonyl is substituted by an acetoxy function [57].

The unique characteristics of the structures of phorbaketals (45-58) and alotaketals (60-64) have inspired many synthetic studies that have been recently reviewed [58]. Here, we outline the recent effort of Tong et al. that accomplished an asymmetric total synthesis of (-)-phorbaketal A (45) and (-)-alotaketals A-B (60-61) by a novel approach based on the cyclization of vinyl epoxy $\delta$ - keto-alcohols [59]. It is worth noting that the tricyclic spiroketal tricycle intermediate was obtained on an impressive $4.5 \mathrm{~g}$ scale. To complete the synthesis, the installation of the terminal alkene allowed the late-stage introduction of various side chains via cross-metathesis reaction (the corresponding aldehyde olefination 
strategy was unsuccessful), allowing access to five structurally different tricyclic spiroketal alotane-type sesterterpenoids. Moreover, in 2020, Lee and coworkers [60] reported on a novel gold-mediated spiroketalization of an epoxy alkyne followed by the rearrangement into the corresponding allylic alcohol being applied to the total synthesis of (-)aloketal A, carried out through 11 steps from 4-hydroxycarvone.<smiles>C=C(C)CCC/C(C)=C/C1CC(=C)C[C@]2(C=C(CO)[C@H]3CC(=O)C(C)=C[C@H]3O2)O1</smiles>

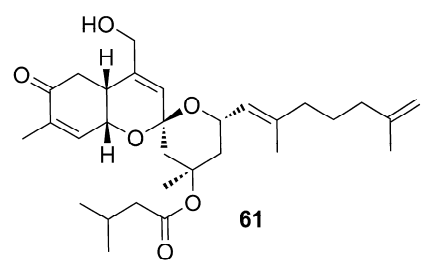<smiles>C=C(C)CCC/C(C)=C/[C@@H]1C[C@](C)(OC(C)=O)C[C@]2(C=C(CO)[C@H]3CC(=O)C(C)=C[C@H]3O2)O1</smiles><smiles>CC(=O)O[C@H]1C[C@@H]2C(CO)=C[C@]3(C[C@H](OC(C)=O)C[C@@H](/C=C(\C)CCC=C(C)C)O3)O[C@H]2C=C1C</smiles><smiles>CC(=O)O[C@]1(C)C[C@H](/C=C(\C)C/C=C/C(C)(C)O)O[C@@]2(C=C(CO)[C@H]3CC(=O)C(C)=C[C@H]3O2)C1</smiles>

Figure 17. Chemical structures of Alotaketals A-B (60-61) isolated from Hamigera sp., and Alotaketals C-E (62-64) isolated from Phorbas sp.

Some authors also propose a possible biosynthetic route for the formation of these natural products (Scheme 3, paragraph 5.1.8) [61].

\section{Ansellones}

The first member of the ansellone sesterterpenoid family is ansellone A (65) (Figure 18) from the nudibranch Cadlina luteomarginata and the sponge Phorbas sp., collected in British Columbia, Canada [62]. Compound 65 was identified as the main component in the organic extract from both organisms. It has an unprecedented ansellane tricycle skeleton. This new group of sesterterpenoids is biogenetically related to alotaketals and phorbaketals [62,63]. Through HRESIMS and NMR analyses, it was possible to identify the tetracyclic structure of ansellone A (65) and the positions of its double bonds and ring substituents. Ansellone A (65) is sequestered by C. luteomarginata from a Phorbas sp. diet [62].

As previously mentioned, in the 2013 study by Daoust et al., where alotaketals were identified, ansellone B (66) and secaepoxyansellane A (71) were also identified [56]. Following this work, Wang and coworkers (2016) identified ansellones D-G (67-70) (Figure 18) [57].

The ansellones (65-70) are tetracyclic sesterterpenoids. The secoepoxyansellone A (72) has three six-membered rings, one of them linked to an epoxide. Ansellones B (66) and $C$ (67), epimers at C-13, feature an unprecedented heterocyclic skeleton that contains an oxocane ring [56]. Ansellone A (65) and E (69) are epimers whose difference lies in the configuration at C-11; ansellone D (68) has a methoxy instead of a hydroxy group in the same orientation as ansellone A (65). Ansellone F (70) displays two epoxide functions and ansellone $G(71)$ has an $\alpha, \beta$-unsaturated carbonyl function [57].

Due to its activity as an HIV latency-reversing agent, ansellone A (65) has attracted interest and, very recently [64], the total synthesis of ansellone A (65) and B (66) and analogues has been reported [63]. The key reaction proposed by Tong and coworkers is a Prins cyclization reaction, enabled using the TfO group for stabilization of the acid-labile tertiary allylic alcohol. The asymmetric synthesis of three ansellane-type compounds, i.e., (-)-ansellone A (65) and B (66) and (+)-phorbadione (75), was accomplished in 16-23 steps from the commercially available (+)-sclareolide. SAR studies showed that the alcohol analogue exhibits a better activity than 65 . 


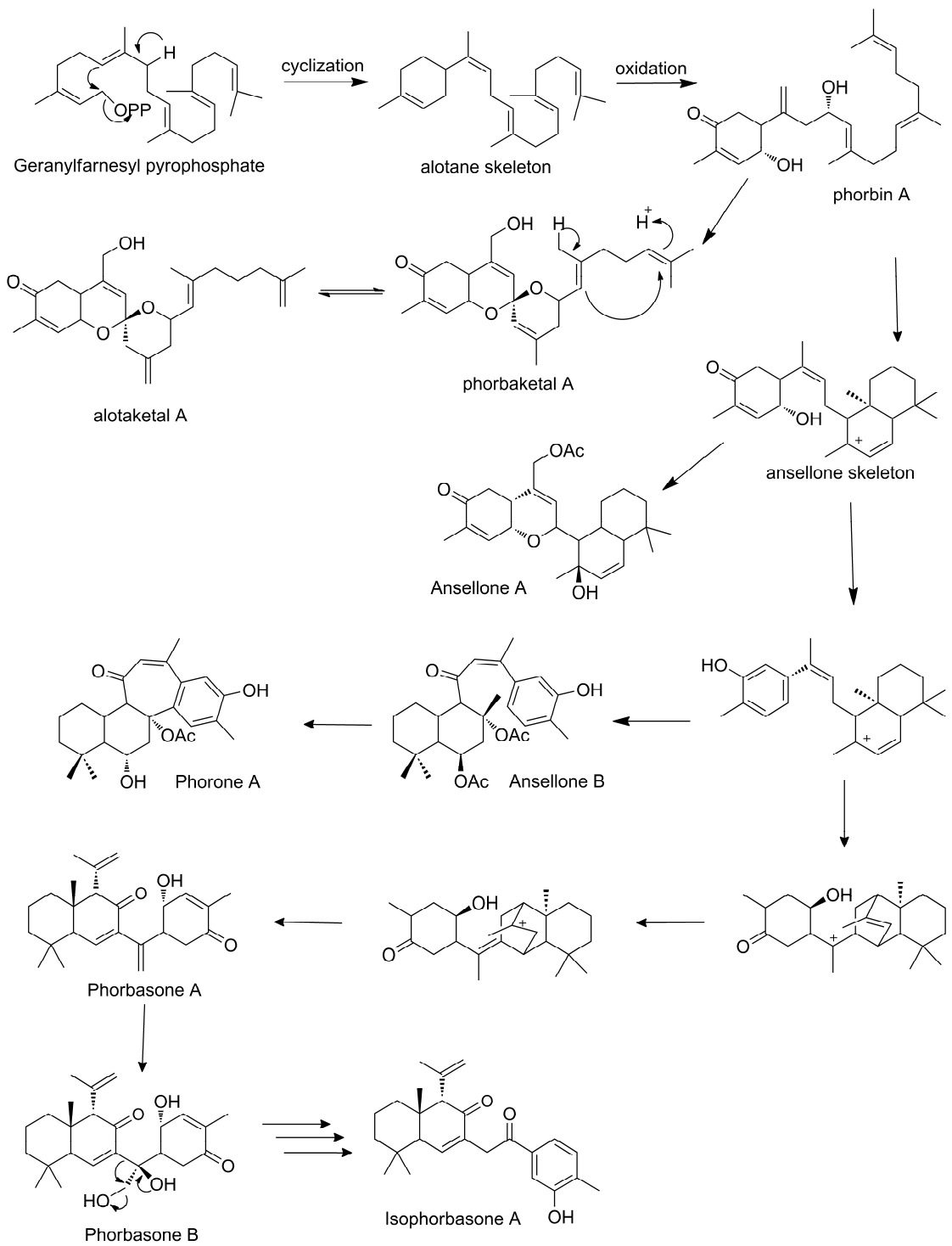

Scheme 3. Proposed biosynthesis of sesterterpenoids of Phorbas (adapted from Wang et al., 2012).

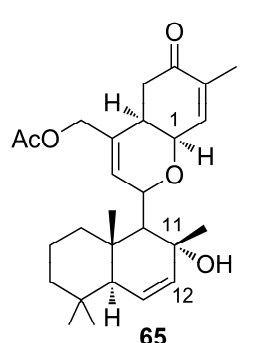

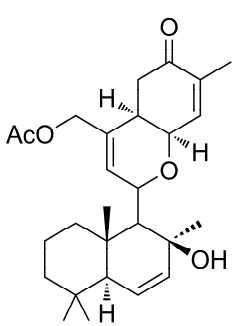

69

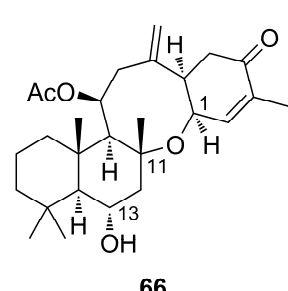

66

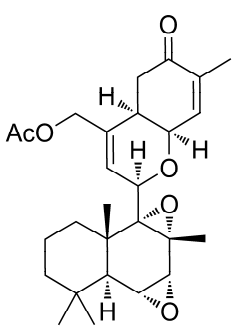

70

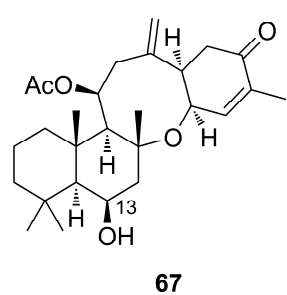

67

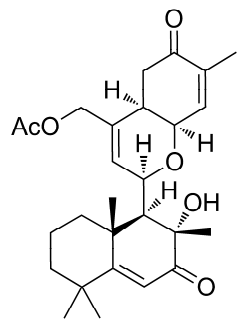

71

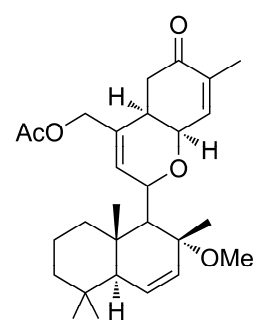

68

Figure 18. Chemical structures of Ansellones A-G (65-71) and Secoepoxyansellone A (72). 


\section{Anvilones}

Anvilones represent another group of sesterterpenoids identified by Wang and coworkers (2016) from Phorbas sp. collected in British Columbia, Canada. Anvilones A-B (73-74) have the unprecedented "anvilane" sesterterpenoide carbon skeleton [57]. They were identified by ESI-MS and NMR and are tetracyclic sesterterpenoids. Anvilone B (74) differs from A (73) for the addition of an acetoxy functionality (Figure 19).<smiles>[R2]C1([R2])C=C(C)C(=O)CC1C1=C[C@H](O)[C@@H]2[C@@](C)(C1)C[C@@H](OC(C)=O)[C@@H]1C(C)(C)CCC[C@]12C</smiles>

$$
\begin{array}{lll} 
& \mathbf{R}_{\mathbf{1}} & \mathbf{R}_{\mathbf{2}} \\
\mathbf{7 3} & \mathrm{H} & \mathrm{H} \\
\mathbf{7 4} & \text { OAC } & \mathrm{H}
\end{array}
$$

Figure 19. Chemical structures of Anvilones A-B (73-74).

Phorbadione

The phorbadione (75) was isolated by Daoust and coworkers in 2013, together with ansellone B (66), secoepoxyansellone A (72), and alotaketal C (62) from samples of Phorbas sp. collected in British Columbia. ESIMS and NMR data of 75 showed great similarity with ansellone $A(65)$, due to the presence of the cyclohexenone and dihydropyran rings. Phorbadione (75) is different from ansellone A (65) due to an extra unsaturation and an $\alpha, \beta$-unsaturated carbonyl function in the ring B [56] (Figure 20).<smiles>[CH2+][C@]12CCCC(C)(C)C1=CC(=O)C(C)=C2[C@H]1C=C(COC(C)=O)[C@H]2CC(=O)C(C)=C[C@H]2O1</smiles>

75

Figure 20. Chemical structure of Phorbadione (75).

Phorbasones

Phorbasones A and B (76-77) (Figure 21) are sesterterpenoids identified together with phorbaketals [65] from a specimen of Phorbas sp. collected in Korea. It is likely that ansellones (65-71), phorbaketals (45-58), and phorbasones (76-77) are biogenetically linked (Scheme 3, paragraph 5.1.8). Complete structures of phorbasones A-B (76-77) were elucidated by spectroscopic techniques and chemical reactions. They have a bicyclic structure connected by a small side chain to a cyclohexanone. The difference between them resides in the bridge-chain, as phorbasone $\mathrm{B}(77)$ has a hydroxymethylene and an additional hydroxyl group, and phorbasone A (76) possesses a methylene function at 
the same position. The absolute stereochemistry of compounds was determined by the Mosher's ester method and NMR data.<smiles>C=C(C1=CC2C(C)(C)CCC[C@]2(C)C(C(=C)C)C1=O)C1CC(=O)C(C)=C[C@H]1O</smiles>

76<smiles>C=C(C)[C@H]1C(=O)C([C@](O)(CO)C2CC(=O)C(C)=C[C@H]2O)=CC2C(C)(C)CCC[C@@]21C</smiles>

77

Figure 21. Chemical structure of Phorbasones A and B (76-77).

One year later, a further study carried out with samples from Phorbas collected in Korea, and from which ansellone B (66) was identified, allowed the identification of a new structure called isophorbasone A (78) (Figure 22) [66]. Compound 78 presents the bridge-chain containing one more carbon unit, and the cyclohexanone ring is replaced by phenol when compared to phorbasone A (76). In addition, data from this work allowed the identification of phorone A (80) (Figure 22), in which the tetracyclic skeleton consisting of a bicyclic system (i.e., decalin, similar to those of phorbasones) is fused to a cycloheptanone ring, fused in turn to a fourth phenyl ring [66].<smiles>C=C(C)[C@H]1C(=O)C(CC(=O)c2ccc(C)c(O)c2)=C[C@]2(C)C(C)CCC[C@]12C</smiles>

78<smiles>C=C(C1=CC2(C)C(C)(C)CCC[C@]2(C)[C@H]1C(=C)C)[C@H]1CC(=O)C(C)=C[C@H]1OC(C)=O</smiles>

79<smiles></smiles>

Figure 22. Chemical structures of Isophorbasone A (78), Phorbasone A Acetate (79), and Phorone A (80).

\section{Suberitenones}

Sesterterpenoids of the suberitone type were isolated and identified from the sponge Phorbas areolatus, collected in Antarctica. The main feature of these substances is the rare suberitane skeleton. In addition to the already known suberitenones A and B (81-82) and oxaspirosuberitenone (83), the new isosuberitenone B (84), 19-episuberitenone B (85), and isooxaspirosuberitenone (86) were isolated (Figure 23) [67]. Until then, these substances were considered markers of the Suberites genus, the only one in which they had been identified. The discovery from Phorbas excludes suberitanes as chemotaxonomic markers.

This sesterterpenoids were identified based on HRMS and NMR data analysis by comparisons with those of the same group already reported. Suberitenone A (81) has a double bond at C-13 absent in B (82), which has a hydroxyl at this position. The HRMS data analysis showed that isosuberitenone B (84) and suberitenone B (82) are isomers. The analysis of ${ }^{1} \mathrm{H}-\mathrm{NMR}$ and HMBC spectra showed that the difference between the two compounds resides in the position of the acetoxy substituent, which in isosuberitenone B (84) is on the cyclohexanone ring, while in suberitenone B (82) it is located on ring B. The epimer at C-19 of $\mathbf{8 2}$ is 19-episuberitenone B (85). As observed for suberitenone B (82) and isosuberitenone B (84), isooxaspirosuberitenone (86) has NMR signals very similar to oxaspirosuberitenone (83), with the difference being the position of the acetoxy substituent group (Figure 23). Interestingly, these structures come from a 1,4 nucleophylic addition and cyclization process which involves the alcohol group at C-13 and the enone of the $\mathrm{D}$ ring, thus resulting in a rare structure in natural products [67]. 


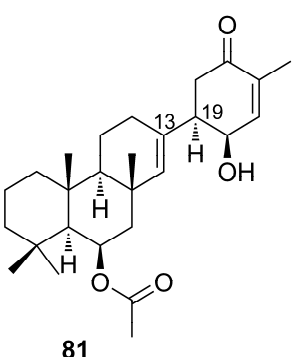

81

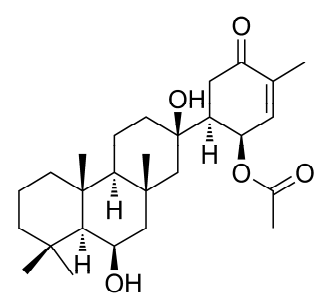

84<smiles>CC(=O)OC1CC2(C)CC(O)([C@H]3CC(=O)C(C)=CC3O)CCC2[C@@]2(C)CCCC(C)(C)[C@H]12</smiles>

82

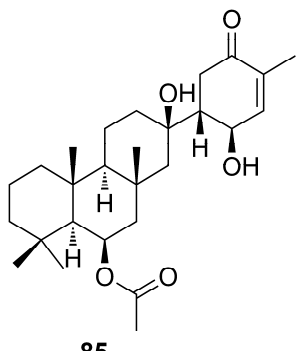

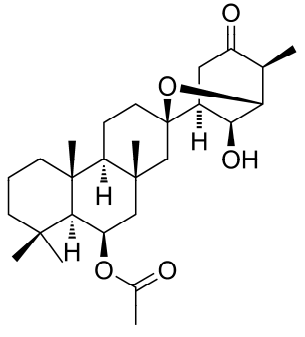

83

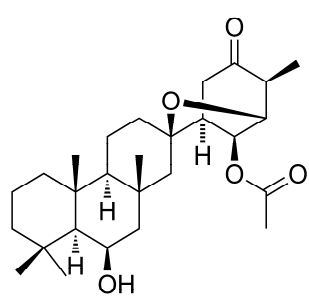

86

Figure 23. Chemical structures of Suberitenones and natural products derivatives (81-86).

Putative Biosynthetic Pathway of Sesterterpenoids from Phorbas

Some authors have already proposed biosynthetic routes for the formation of sesterterpenoids found in Phorbas. As being found in the same species, several of these natural products can share stages on the same route. The main hypothesis is that they all start from the geranyl-farnesyl pyrophosphate, which through cationic cyclizations, oxidation, and rearrangements, would lead to different skeletons [66].

Phorbaketals (45-58) and alotaketals (60-64) are compounds with a spiral ring originated from the geranyl-farnesyl pyrophosphate unit. A pyrophosphate-generated allylic cation is attacked by proximal olefin to form the alotane skeleton and, after successive oxidations, it produces phorbin A (59), phorbaketal (45-58), and alotaketal (60-64) [61].

Phorbin A (59) is considered a precursor of a series of Phorbas steroids, such as phorbasones (76-77). The farnesyl part of phorbin A (59) undergoes cationic cyclization, forming the skeleton of ansellone, a shared intermediate between phorbasones (76-77), ansellone (65-71), and phorone A (80), which has a common fused bicyclic ring. The ansellone skeleton reorganizes itself through cationic cyclization, forming a bicyclic structure which undergoes successive proton migrations and ring cleavage. This sequence of reactions leads to the tricyclic structure of phorbasone A (76), which is hydroxylated to phorbasone B (77). For the formation of isophorbasone A (78), phorbasone B (77) passes through several stages, such as oxidation, dehydration, rearrangement, and tautomerization of the hexenone keto-enol (Scheme 3) [65,66].

The ansellone skeleton is the precursor of the ansellone (65-71) class and phorone A (80). Wang et al. link the biosynthetic route of the ansellones with that of the anvillones (73-74) and alotaketals (60-64), found in Phorbas sp. collected in British Columbia (Scheme 4) [57]. 


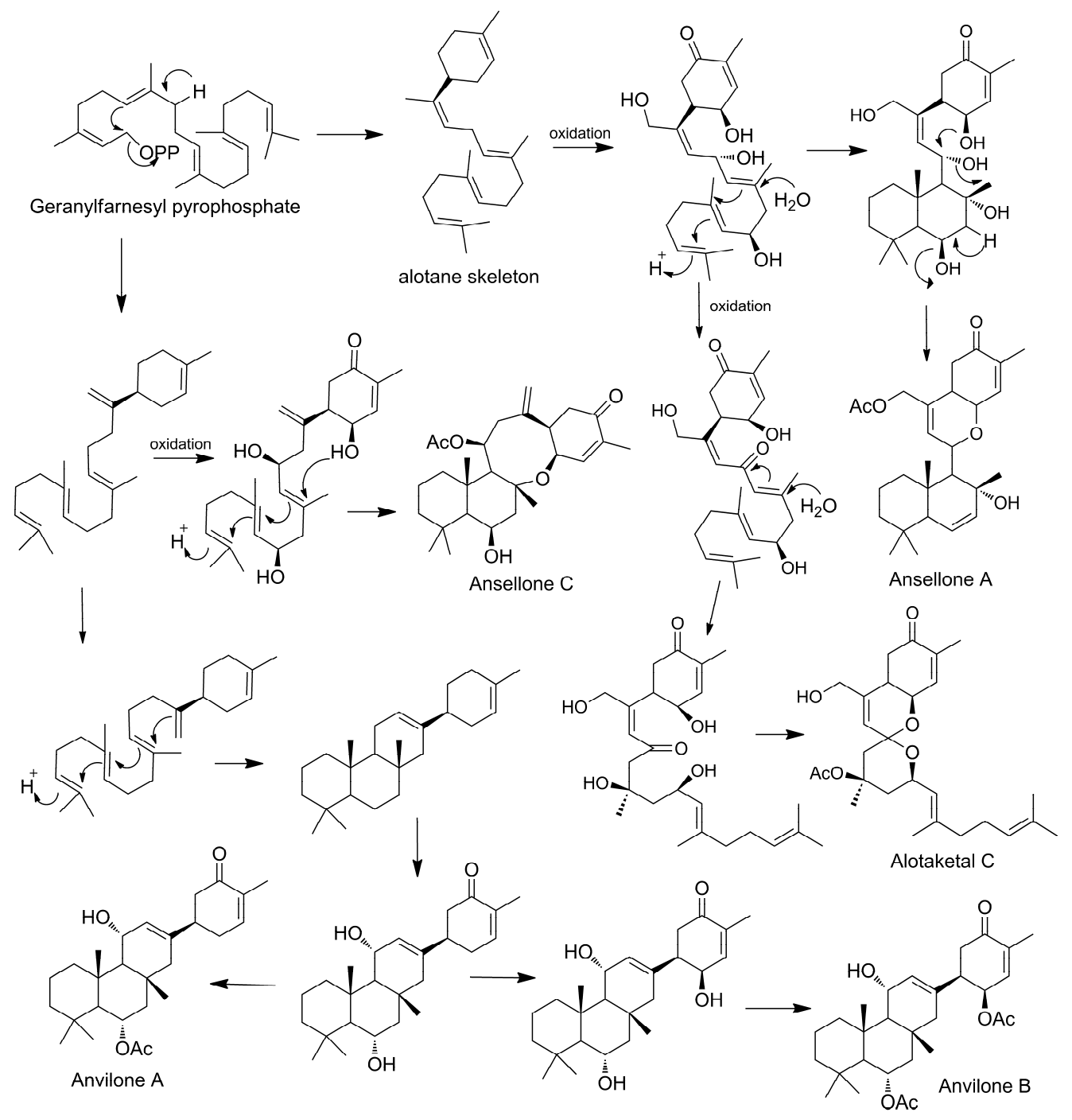

Scheme 4. Proposed biosynthesis of sesterterpenoids identified in Phorbas (from Wang et al., 2016).

\subsubsection{Diterpenoids}

\section{Phorbasins}

In 2000, Vuong and Capon identified a diterpene with a novel skeleton, named phorbasin A (87), from a Phorbas sp. sample collected in Australia [31]. NMR and ESI-MS analyses allowed the identification of this novel skeleton as a conjugated polyene attached to a monocyclic unit. The molecule was unstable and underwent decomposition during the analysis. Therefore, the absolute stereochemistry of the three chiral centers of phorbasin A (87) remains undetermined. The enantiomer portrayed in Figure 24 displays the arbitrary absolute stereochemistry suggested by authors.<smiles>CC(=O)C1C(O)C=C(C)C(=CC=C(C)C=CC=C(C)C)C1O</smiles><smiles>CC(C)C/C=C/C(C)C/C=C/C(=O)C1C(O)C=C(CO)C(=O)C1O</smiles><smiles>CC(/C=C/CC(C)C)=C\C=C\C1C(O[N+](=O)[O-])C=C(CO)C(=O)C1O</smiles>

Figure 24. Chemical structures of Phorbasins A-C (87-89).

One year later, two additional phorbasins were identified, namely, phorbasin B and C (88-89) [68]. The relative stereochemistry of phorbasin B (88) was attributed based on coupling constant values and molecular modeling data that provided theoretical measures of the dihedral angles. The stereo structure was established by comparison with other 
similar skeletons having the same cyclohexenone substructure. Phorbasin C (89) was spectroscopically very similar to phorbasin B (88). The molecular formula for phorbasin $C$ (89) differed from phorbasin B (88) by 42 mass units (acetyl unit), and the ${ }^{1} \mathrm{H} N M R$ spectrum of phorbasin $C(89)$ revealed signals related to the presence of a characteristic methyl acetate group. Due to the lack of material and the instability of phorbasin A (87) and $C$ (89), their absolute stereochemistry could not be determined. One year later, the total synthesis of phorbasin C (89) was carried out by Macklin and coworkers, finally allowing the elucidation of the relative and absolute configuration of this phorbasin [69]. The skeleton of phorbasins B-C (88-89) is very similar to phorbasin A (87) (Figure 24). They differ by the side chain and by substituents on the cyclohexenone ring. These diterpenoids are likely to share a common biosynthetic pathway, even if not occurring as co-metabolites [68].

Following these two studies, Zhang and Capon (2008) reisolated the phorbasins B-C (88-89) and confirmed their stereochemistry. Additionally, they identified new analogs named phorbasins D-F (90-92) (Figure 25), which incorporate a somewhat unprecedented terpenyl-taurine residue (2-aminoethanesulfonic acid) [70]. ESI-MS and NMR analyses allowed the identification of phorbasin $\mathrm{D}(\mathbf{9 0})$. The comparison of NMR data of phorbasins $\mathrm{B}-\mathrm{C}(\mathbf{8 8}-\mathbf{8 9})$ and D (90) showed the presence of different functional groups on the cyclohexenone ring. While in phorbasins $\mathrm{B}-\mathrm{C}(\mathbf{8 8}-\mathbf{8 9})$ the substituent is a hydroxymethylene, a taurinyl group is present in phorbasin $\mathrm{D}(\mathbf{9 0})$.<smiles>C/C(=C\C=C\C(C)C=CCC(C)C)[C@H]1C(O)C=C(CNCCS(=O)(=O)O)C(=O)C1O</smiles>

90

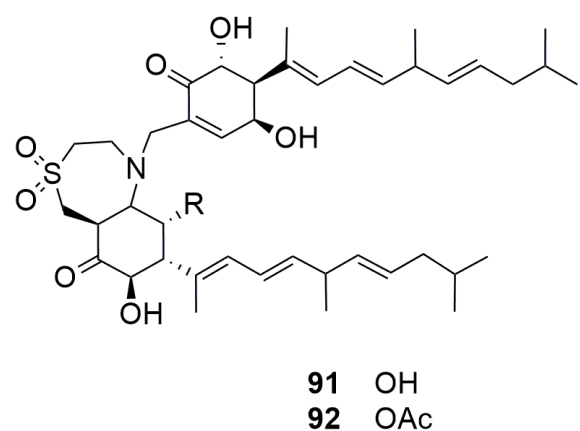

Figure 25. Chemical structures of Phorbasins D-F (90-92).

Phorbasins E-F (91-92) are actually dimers, probably derived from phorbasin B or C (88-89), fused by a seven-membered heterocyclic ring which incorporates a taurinyl residue, an unprecedented feature in natural product skeletons [70]. Analysis of the structures that form the dimers suggested that they may have the same biosynthetic origin and, therefore, a common absolute stereochemistry. The difference between these dimers is the presence of an acetate substituent linked to the phorbasin F (92), which is absent in $\mathrm{E}(\mathbf{9 1})[31,68,70]$.

In 2008, Lee and coworkers identified three novel diterpenes from Phorbas gukhulensis, collected in South Korea, that were named phorbasins G-I (93-95) [71] (Figure 26). These molecules, identified by FAB-MS and NMR experiments, feature a cyclohexane ring, in contrast to their previously discussed congeners, which exhibits a cyclohexene moiety. Phorbasin G (93) has a taurine residue as a substituent on the ring, very similar to that found in phorbasin D (90). Phorbasin H (94) displays a carboxylic function, as well as phorbasin I (95), which differs from the former by the position of a double bond in the side chain [56]. Recently, the synthesis of phorbasin $\mathrm{H}$ (94) was carried out and the absolute configuration of the natural product was determined as $S$ [72]. A dereplication work through LCMS showed the presence of these phorbasins G-I in the extract of P. amaranthus [73].

A few months later, Zhang et al. identified five additional phorbasins, i.e., phorbasins G-K (96-100) (Figure 27) [74]. Analysis of ESI-MS and NMR spectra revealed that phorbasin G (96) is a desoxy analogue of phorbasin B (88), while phorbasin H (97) is an acetate derivative of phorbasin $\mathrm{G}(\mathbf{9 6})$ sharing the same absolute stereochemistry. Phorbasin I (98) has an ethoxy group at $\mathrm{C} 17$, and phorbasin J (99) bears two ethoxy groups, respectively at 
$\mathrm{C} 2$ and $\mathrm{C} 17$, and so both phorbasins can be regarded as ethoxy derivatives of phorbasin $\mathrm{H}$ (97). Phorbasin K (100) was reported as the dihydro analogue of phorbasin B (88). Phorbasins I and J (98-99) are likely solvolysis artifacts generated by storage in ethanol.<smiles>CC(C)=CCCC(C)/C=C/C=C(\C)C1CCC(C(=O)NCCS(=O)(=O)[O-])CC1</smiles><smiles>CC(C)=CCCC(C)/C=C/C=C(\C)C1CCC(C(=O)O)CC1</smiles><smiles>CC(C=CC=C(C)C1CCC(C(=O)O)CC1)=CCCC(C)C</smiles>

Figure 26. Chemical structures of Phorbasins G-I (93-95) identified by Lee et al. (2008).

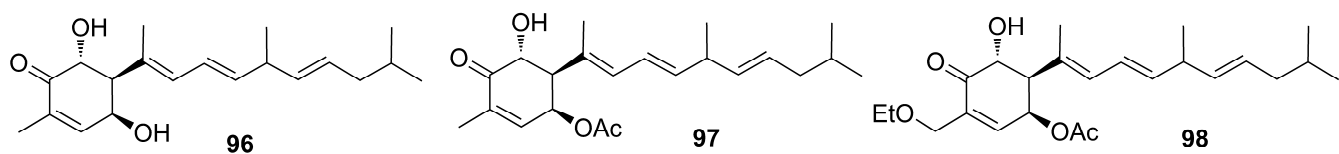<smiles>CCOCC1C(=O)[C@H](O)C(C(C)=CC=CC(C)C=CCC(C)C)C(OCC)C1OC</smiles>

Figure 27. Chemical structures of Phorbasins G-K (96-100) identified by Zhang and Capon, 2008.

\section{Gagunins}

Seven diterpenoids, named gagunins A-G (101-107) (Figure 28), have been identified [75] for the first time from a species collected in South Korea. They have the core structure of homoverrucosane, with three fused carbon rings, i.e., cyclopentane, cyclohexane, and cycloheptene. The main difference with the core structure of homoverrucosane is the stereochemistry of the junction between the five and six carbon rings. Another feature is that they are highly oxygenated structures with a variety of functions.

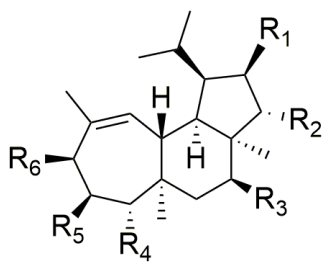

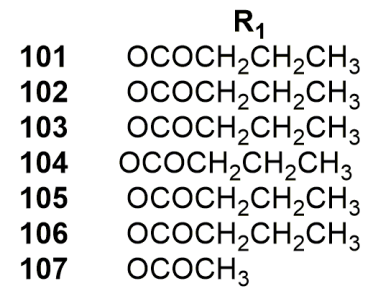

$\mathbf{R}_{2}$
$\mathrm{CH}_{3}$
$\mathrm{R}_{1}$
$\mathrm{OCOCH}_{3}$
$\mathrm{H}$
$\mathrm{H}$
$\mathrm{H}$
$\mathrm{H}$

$\mathrm{R}_{3}$
$\mathrm{R}_{1}$
$\mathrm{R}_{1}$
$\mathrm{R}_{1}$
$\mathrm{R}_{1}$
$\mathrm{R}_{1}$
$\mathrm{R}_{1}$
ococh
$\mathrm{CH}_{2} \mathrm{CH}_{3}$

$\begin{array}{ccc}\mathbf{R}_{\mathbf{4}} & \mathbf{R}_{\mathbf{5}} & \mathbf{R}_{\mathbf{6}} \\ \mathrm{R}_{1} & \mathrm{OCOCH}_{3} & \mathrm{OH} \\ \mathrm{R}_{1} & \mathrm{OCOCH}_{3} & \mathrm{OH} \\ \mathrm{R}_{1} & \mathrm{OCOCH}_{3} & \mathrm{OH} \\ \mathrm{R}_{1} & \mathrm{OCOCH}_{3} & \mathrm{OH} \\ \mathrm{OH} & \mathrm{O}_{1} & \mathrm{OCOCH}_{3} \\ \mathrm{OH}_{1} & \mathrm{OH} & \mathrm{OCOCH}_{3} \\ \mathrm{R}_{3} & \mathrm{OH} & \mathrm{OCOCH}_{3}\end{array}$

Figure 28. Chemical structures of gagunins A-G (101-107).

The gagunins' structures were defined through FAB-MS, IR, and NMR data analyses. Structural elucidation of gagunin A (101) was achieved by its conversion into a 
perohydroxyl derivative to remove ester chains, making the structural elucidation easier. Gagunins A-C (101-103) differ from each other by the two substituents on the cyclopentane ring. Gagunins D-F (104-106) differ by the three substituents on the cycloheptene ring. Gagunin $G$ (107) shares the substitution pattern of the cycloheptene ring with gagunin $F$ (106) and differs from the latter by a substituent on the cyclopentane ring [75].

In 2008, Jang and coworkers, from the same Phorbas sp. sample collected in Korea, identified phorbasin $\mathrm{H}$ (94), as previously mentioned, and six known gagunins, i.e., gagunins A-D (101-104) and F-G (106-107), and ten new gagunins, named $\mathrm{H}-\mathrm{Q}$ (108-117) (Figure 29) [76].

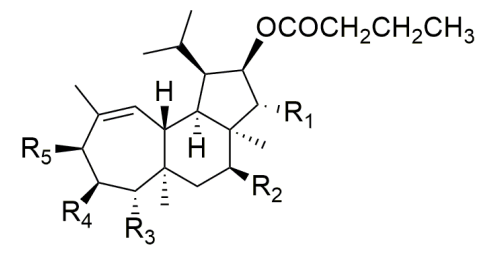

\begin{tabular}{|c|c|c|c|c|c|}
\hline 08 & $\begin{array}{c}\mathbf{R}_{1} \\
\mathrm{OCOCH}_{2} \mathrm{CH}_{2} \mathrm{CH}_{3}\end{array}$ & $\begin{array}{c}\mathbf{R}_{2} \\
\mathrm{OCOCH}_{2} \mathrm{CH}_{3}\end{array}$ & $\begin{array}{l}\mathbf{R}_{3} \\
\mathbf{R}_{1}\end{array}$ & $\begin{array}{l}\mathbf{R}_{4} \\
\mathrm{OCOCH}\end{array}$ & $\begin{array}{l}\mathbf{R}_{5} \\
\mathrm{OH}\end{array}$ \\
\hline 10 & $\mathrm{OCOCH}_{2} \mathrm{CH}_{2} \mathrm{CH}_{3}$ & $\mathrm{OCOCH}_{3}$ & $\mathrm{R}_{1}$ & $\mathrm{OCOCH}_{3}$ & $\mathrm{OH}$ \\
\hline & $\mathrm{COCH}_{2} \mathrm{CH}_{3}$ & $\mathrm{OCOCH}_{2} \mathrm{CH}_{2} \mathrm{CH}_{3}$ & $\mathrm{R}_{2}$ & $\mathrm{OCOCH}_{3}$ & $\mathrm{OH}$ \\
\hline 1 & $\mathrm{OCOCH}_{2} \mathrm{CH}_{2} \mathrm{CH}_{3}$ & $\mathrm{R}_{1}$ & $R_{1}$ & $\mathrm{OCO}$ & $\mathrm{OH}$ \\
\hline 12 & $\mathrm{H}$ & $\mathrm{OCOCH}_{3}$ & $\mathrm{OCOCH}_{2} \mathrm{CH}_{2}$ & $\mathrm{OCOCH}_{3}$ & $\mathrm{OH}$ \\
\hline 113 & $\mathrm{H}$ & $\mathrm{OCOCH}_{2} \mathrm{CH}\left(\mathrm{CH}_{3}\right)_{2}$ & $\mathrm{OCOCH}_{2} \mathrm{CH}_{2} \mathrm{C}$ & $\mathrm{OCOCH}_{3}$ & $\mathrm{OH}$ \\
\hline 114 & $\mathrm{H}$ & $\mathrm{OCOCH}_{3}$ & $\mathrm{OCOCH}_{2} \mathrm{CH}_{2} \mathrm{CH}_{3}$ & Or & $\mathrm{COC}$ \\
\hline 115 & $\mathrm{OCOCH}_{2} \mathrm{CH}_{2} \mathrm{CH}$ & $\mathrm{OH}$ & $\mathrm{R}_{1}$ & Or & OCOC \\
\hline 116 & $\mathrm{COCH}_{2} \mathrm{CH}$ & $\mathrm{R}_{1}$ & ococ & (n) & $\mathrm{OH}$ \\
\hline 117 & $\mathrm{OCH}_{2} \mathrm{CH}_{2}$ & $R_{1}$ & $R$ & $\mathrm{COCH}_{2} \mathrm{C}$ & $\mathrm{OH}$ \\
\hline
\end{tabular}

Figure 29. Chemical structures of Gagunins H-Q (108-117).

Gagunins H-M (108-113) are very similar to gagunins A-D (101-104), showing changes in the substitution pattern of the cyclohexane ring differently from compounds 101-104. Gagunins N-O (114-115) have a close similarity with gagunins F-G (106-107), but with a different substitution pattern on the cyclohexane ring. Gagunins $\mathrm{P}-\mathrm{Q}(\mathbf{1 1 6}-\mathbf{1 1 7})$ have an identical substitution pattern in the cyclopentane and cyclohexane rings, and changes are in the substituent groups on the cycloheptene ring (Figure 29) [76].

\subsubsection{Tetraterpenoids}

To date, the only tetraterpenoids identified from the genus Phorbas are gukulenins, which have an unprecedented bis-tropolone skeleton. Gukulenins were identified from sample of P. gukhulensis, collected in South Korea. Gukulenins A-F (118-123) look like pseudodimers of the gagunines, also found in this species, but the different positions of substituting groups may indicate that they have a different precursor. They have very diverse oxygenated side chains, but they are smaller than the oxygenated groups found in gagunins. Moreover, they also have aminoacidic chain linked to one of the two tropolone unit $[29,30]$ (Figure 30).

It is worth mentioning that the synthesis of this dimeric tetraterpenoid structure has been recently explored by D. Tymann and coworkers, who proposed a two-carbon ring expansion photochemical mechanism to get an alpha-tropolonic ether ring, starting from (-)-piperitone. The same group states that total synthesis of gukulenin A is under investigation [77].

\subsection{Miscellaneous}

\subsubsection{Other Compounds Identified from P. topsent $i$}

The $p$-hydroxybenzaldehyde (124) was identified in the same study where the alkaloid zarzissine (13) was isolated (Figure 31). This compound was identified in the sponge $P$. topsenti (previously P. paupertas) collected from the Mediterranean Sea off the coast of Tunisia [37]. 


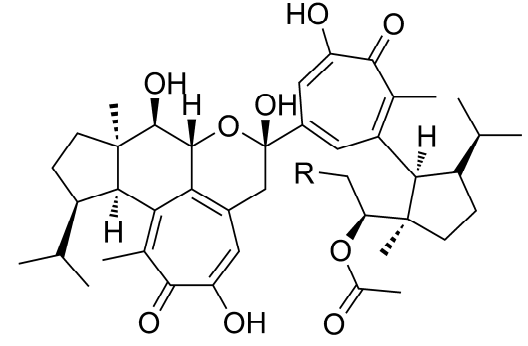

$118 R=0$

$119 \mathrm{R}=\mathrm{OH}$

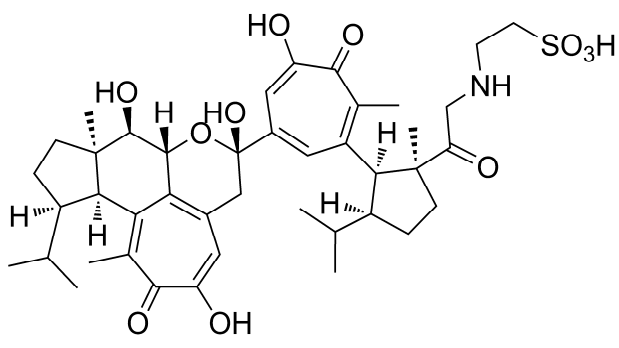

122

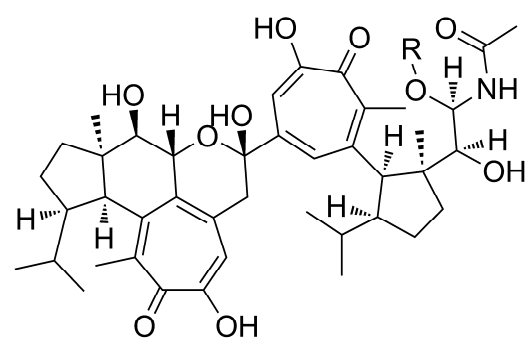

$120 \mathrm{R}=\mathrm{CH}_{3}$

$121 \mathrm{R}=\mathrm{H}$

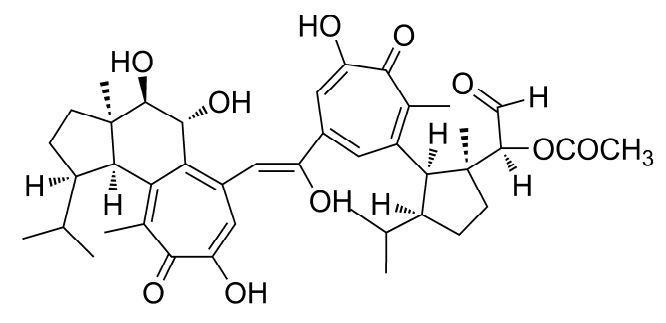

123

Figure 30. Chemical structures of Gukulenins A-F (118-123).<smiles>O=Cc1ccc(O)cc1</smiles>

124

Figure 31. Chemical structure of the $p$-hydroxybenzaldehyde (124).

The carotenoids astaxanthin (125) and adonirubin (126) (Figure 32) were isolated from a species of Phorbas topsenti collected off Marseille (France), in addition to the alkaloids phorbatopsins (14-16) [26].<smiles>CC1=C(/C=C/C(C)=C/C=C/C(C)=C/C=C/C=C(C)/C=C/C=C(C)/C=C/C2=C(C)C(=O)[C@@H](O)CC2(C)C)C(C)(C)C[C@H](O)C1=O</smiles><smiles>CC1=C(/C=C/C(C)=C/C=C/C(C)=C/C=C/C=C(C)/C=C/C=C(C)/C=C/C2=C(C)C(=O)[C@@H](O)CC2(C)C)C(C)(C)CCC1=O</smiles>

Figure 32. Chemical structures of the Astaxanthin (125) and Adonirubin (126).

In the framework of the study mentioned above, two sulfonic acids, taurine (127) and taurobetain (128), were isolated (Figure 33) [26]. 
<smiles>NCCS(=O)(=O)O</smiles>

127<smiles>C[N+](C)(C)CCS(=O)(=O)[O-]</smiles>

128

Figure 33. Chemical structures of Taurine (127) and Taurobetain (128).

\subsubsection{Other Compounds Identified from P. amaranthus}

Recently, a dereplication study, based upon comparison of HRMS fragmentation pathways, allowed the annotation of 18 known Phorbas metabolites from the extract of $P$. amaranthus, collected in Brazil. Among others, phorbasins (87-88, 97-100), phorbaketals $(45,46$ or 47,49$)$, isophorbasone (78), ansellones (72), anvillones (80), and phorbasterones (29-36) [73] were isolated.

Bioinformatic analyses of MS/MS data (Global Natural Product Social Molecular Networking (GNPS) [78] of the same extract allowed the identification of 17 additional metabolites, most of them being lysophospholipids (LPL) (129-130), carotenoids (131), and sterols (132-133) (Figure 34). The GNPS also suggested 29 metabolites annotated through a molecular subnetwork. Some examples of these metabolites are shown in Figure 34 [73].<smiles>CC(C)CCCCCCCCCCCCC(C)CC(=O)OCC(O)COP(=O)([O-])OCC[N+](C)(C)C</smiles>

129<smiles>CCCCCCCCCCCOCC(O)COP(=O)([O-])OCC[N+](C)(C)C</smiles>

130<smiles>CC1=C(/C=C/C(C)=C/C=C/C(C)=C/C=C/C=C(C)/C=C/C=C(C)/C=C/C2=C(C)C(=O)[C@@H](O)CC2(C)C)C(C)(C)CC(O)C1=O</smiles>

131

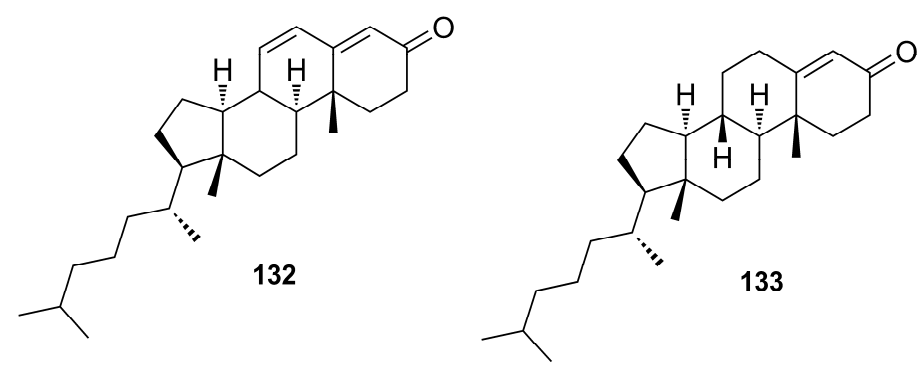

Figure 34. Chemical structures of compounds detected by GNPS in the organic extract P. amaranthus (129-133).

\section{Bioactivity of Compounds Isolated from Sponges of the Genus Phorbas}

The oceans are places on the Earth containing a wide spectrum of natural resources. The advent of new technologies allowed for profound study of marine biochemical diversity and the discovery of new bioactive marine natural products (MNPs). The complex habitats and exposure to extreme conditions of light, temperature, $\mathrm{pH}$, salinity, and other external factors induce marine organisms to produce a wide variety of specific and potent active substances that cannot be found elsewhere [79]. The genus Phorbas, as well as several other 
sponges found in the aquatic environment, is a rich source of bioactive natural products such as alkaloids, terpenes, macrolides, steroids, and peptides.

Among the bioactivities described for compounds identified from the genus Phorbas, the cytotoxic activity (Table 1) stands out. However, other bioactivities (Table 2) have been reported. Bioactivity evaluation of pure compounds is often hampered by the low quantity that can be obtained from the natural source. Indeed, some compounds have been evaluated for their pharmacological properties only after being obtained on a larger scale by chemical synthesis.

Table 1. List of MNPs isolated from Phorbas sp. having antiproliferative activity.

\begin{tabular}{|c|c|c|c|c|c|c|}
\hline & Name & Class & Species & Cell Lines & Dose/Concentration & Reference \\
\hline 13 & Zarzissine & Alkaloid & $\begin{array}{l}\text { Phorbas } \\
\text { tenacior }\end{array}$ & $\mathrm{P}-388^{\mathrm{a}}$ & $\mathrm{IC}_{50} 12 \mu \mathrm{g} / \mathrm{mL}$ & {$[37]$} \\
\hline 17 & Phorboxazole A & Macrolide & Phorbas sp. & $\begin{array}{c}\text { KB }^{\mathrm{b}} \\
\text { NSCLC-N6 }^{\mathrm{c}} \\
{\text { HCT- } 116^{\mathrm{d}}}^{\text {HT29 }}{ }^{\mathrm{d}}\end{array}$ & $\begin{array}{c}\mathrm{IC}_{50} 5 \mu \mathrm{g} / \mathrm{mL} \\
\mathrm{IC}_{50} 10 \mu \mathrm{g} / \mathrm{mL} \\
\mathrm{GI}_{50} 4.36 \times 10^{-10} \mathrm{M} \\
\mathrm{GI}_{50} 3.31 \times 10^{-10} \mathrm{M}\end{array}$ & {$[24]$} \\
\hline 19 & Muironolide A & Macrolide & Phorbas sp. & HCT- $116^{d}$ & $\mathrm{IC}_{50} 96.5 \mu \mathrm{g} / \mathrm{mL}$ & [40] \\
\hline 20 & Phorbaside A & Macrolide & Phorbas sp. & HCT-116 ${ }^{d}$ & $\mathrm{IC}_{50} 30.0 \mu \mathrm{M}$ & [44] \\
\hline 22 & Phorbaside C & Macrolide & Phorbas sp. & HCT-116 ${ }^{d}$ & $\mathrm{IC}_{50} 2 \mu \mathrm{M}$ & [44] \\
\hline 23 & Phorbaside D & Macrolide & Phorbas sp. & HCT-116 d & $\mathrm{IC}_{50} 61.9 \mu \mathrm{M}$ & [44] \\
\hline 24 & Phorbaside E & Macrolide & Phorbas sp. & HCT-116 d & $\mathrm{IC}_{50} 10.2 \mu \mathrm{M}$ & [44] \\
\hline 29 & Phorbasterone A & Steroid & $\begin{array}{c}\text { Phorbas } \\
\text { amaranthus }\end{array}$ & HCT- $116^{d}$ & $\mathrm{IC}_{50} 1-3 \mu \mathrm{g} / \mathrm{mL}$ & {$[48,73]$} \\
\hline 30 & Phorbasterone B & Steroid & $\begin{array}{c}\text { Phorbas } \\
\text { amaranthus }\end{array}$ & HCT- $116^{d}$ & $\mathrm{IC}_{50} 1-3 \mu \mathrm{g} / \mathrm{mL}$ & {$[48,73]$} \\
\hline $\begin{array}{l}31- \\
32\end{array}$ & Phorbasterone C & Steroid & $\begin{array}{c}\text { Phorbas } \\
\text { amaranthus }\end{array}$ & HCT- $116^{d}$ & $\mathrm{IC}_{50} 1-3 \mu \mathrm{g} / \mathrm{mL}$ & {$[48,73]$} \\
\hline $\begin{array}{c}33- \\
34\end{array}$ & Phorbasterone D & Steroid & $\begin{array}{c}\text { Phorbas } \\
\text { amaranthus }\end{array}$ & HCT- $116^{d}$ & $\mathrm{IC}_{50} 1-3 \mu \mathrm{g} / \mathrm{mL}$ & {$[48,73]$} \\
\hline 45 & Phorbaketal A & Sesterterpenoid & Phorbas sp. & $\begin{array}{l}\text { A549 c } \\
\text { HT-29 d } \\
\text { HepG2 e }\end{array}$ & $\begin{array}{l}\mathrm{IC}_{50} 11-12 \mu \mathrm{g} \mathrm{mL}^{-1} \\
\mathrm{IC}_{50} 11-12 \mu \mathrm{g} \mathrm{mL}^{-1} \\
\mathrm{IC}_{50} 11-12 \mu \mathrm{gL}^{-1}\end{array}$ & {$[52,54]$} \\
\hline 46 & Phorbaketal B & Sesterterpenoid & Phorbas sp. & $\begin{array}{l}\text { A549 c } \\
\text { HT-29 d } \\
\text { HepG2 e }\end{array}$ & $\begin{array}{l}\mathrm{IC}_{50} 12-460 \mu \mathrm{g} / \mathrm{mL} \\
\mathrm{IC}_{50} 12-460 \mu \mathrm{g} / \mathrm{mL} \\
\mathrm{IC}_{50} 12-460 \mu \mathrm{g} / \mathrm{mL}\end{array}$ & {$[52,54]$} \\
\hline 47 & Phorbaketal C & Sesterterpenoid & Phorbas sp. & $\begin{array}{l}\text { A549 c } \\
\text { HT-29 d } \\
\text { HepG2 e } \\
\text { HT-29 d }\end{array}$ & $\begin{array}{c}\mathrm{IC}_{50} 12-460 \mu \mathrm{g} / \mathrm{mL} \\
\mathrm{IC}_{50} 12-460 \mu \mathrm{g} / \mathrm{mL} \\
\mathrm{IC}_{50} 12-460 \mu \mathrm{g} / \mathrm{mL} \\
\mathrm{LG}_{50} 5-15 \mu \mathrm{M}\end{array}$ & {$[52,54]$} \\
\hline 50 & Phorbaketal N & Sesterterpenoid & Phorbas sp. & $\begin{array}{l}\text { PANC-1 }{ }^{\mathrm{f}} \\
\text { A498 } \mathrm{g} \\
\text { ACHN }\end{array}$ & $\begin{array}{l}\mathrm{IC}_{50} 11.4 \mu \mathrm{M} \\
\mathrm{IC}_{50} 18.7 \mu \mathrm{M} \\
\mathrm{LC}_{50} 24.4 \mu \mathrm{M}\end{array}$ & {$[53]$} \\
\hline 84 & Isosuberitenone B & Sesterterpenoid & $\begin{array}{l}\text { Phorbas } \\
\text { areolatus }\end{array}$ & A549 c & $\mathrm{IC}_{50} 8.8 \mu \mathrm{M}$ & [67] \\
\hline & & & & $\begin{array}{l}\text { HT-29 d } \\
\text { HepG2 e } \\
\text { MCF-7 }^{\text {h }}\end{array}$ & $\begin{array}{l}\mathrm{IC}_{50} 9.0 \mu \mathrm{M} \\
\mathrm{IC}_{50} 7.4 \mu \mathrm{M} \\
\mathrm{IC}_{50} 8.8 \mu \mathrm{M}\end{array}$ & \\
\hline 85 & 19-episuberitenone B & Sesterterpenoid & $\begin{array}{l}\text { Phorbas } \\
\text { areolatus }\end{array}$ & A $549^{c}$ & $\mathrm{IC}_{50} 5.1 \mu \mathrm{M}$ & {$[67]$} \\
\hline & & & & $\begin{array}{l}\text { HT-29 d } \\
\text { HepG2 e } \\
\text { MCF-7 }^{\text {h }}\end{array}$ & $\begin{array}{l}\mathrm{IC}_{50} 6.4 \mu \mathrm{M} \\
\mathrm{IC}_{50} 5.0 \mu \mathrm{M} \\
\mathrm{IC}_{50} 5.1 \mu \mathrm{M}\end{array}$ & \\
\hline 88 & Phorbasin B & Diterpene & Phorbas sp. & $\begin{array}{l}\text { A549 } \\
\text { HT-29 }\end{array}$ & $\begin{array}{l}\mathrm{LG}_{50} 5-15 \mu \mathrm{M} \\
\mathrm{LG}_{50} 5-15 \mu \mathrm{M}\end{array}$ & [70] \\
\hline 89 & Phorbasin C & Diterpene & Phorbas sp. & $\begin{array}{l}\text { A549 c } \\
\text { HT-29 d }\end{array}$ & $\begin{array}{l}\mathrm{LG}_{50} 5-15 \mu \mathrm{M} \\
\mathrm{LG}_{50} 5-15 \mu \mathrm{M}\end{array}$ & [70] \\
\hline
\end{tabular}


Table 1. Cont.

\begin{tabular}{|c|c|c|c|c|c|c|}
\hline & Name & Class & Species & Cell Lines & Dose/Concentration & Reference \\
\hline 91 & Phorbasin E & Terpenyl-taurine & Phorbas sp. & $\begin{array}{l}\text { A549 c } \\
\text { HT-29 d }\end{array}$ & $\begin{array}{l}\mathrm{LG}_{50} 5-15 \mu \mathrm{M} \\
\mathrm{LG}_{50} 5-15 \mu \mathrm{M}\end{array}$ & [70] \\
\hline 101 & Gagunin A & Diterpenoid & Phorbas sp. & $K-562^{a}$ & $\mathrm{LC}_{50} 50.1 \mu \mathrm{g} / \mathrm{mL}$ & [75] \\
\hline 102 & Gagunin B & Diterpenoid & Phorbas sp. & $K-562^{a}$ & $\mathrm{LC}_{50} 10.4 \mu \mathrm{g} / \mathrm{mL}$ & [75] \\
\hline 103 & Gagunin C & Diterpenoid & Phorbas sp. & $K-562^{a}$ & $\mathrm{LC}_{50} 0.71 \mu \mathrm{g} / \mathrm{mL}$ & [75] \\
\hline 104 & Gagunin D & Diterpenoid & Phorbas sp. & $K-562^{a}$ & $\mathrm{LC}_{50} 0.13 \mu \mathrm{g} / \mathrm{mL}$ & [75] \\
\hline 105 & Gagunin E & Diterpenoid & Phorbas sp. & $\mathrm{K}-562^{\mathrm{a}}$ & $\mathrm{LC}_{50} 0.03 \mu \mathrm{g} / \mathrm{mL}$ & [75] \\
\hline 106 & Gagunin F & Diterpenoid & Phorbas sp. & $K-562^{a}$ & $\mathrm{LC}_{50} 0.11 \mu \mathrm{g} / \mathrm{mL}$ & [75] \\
\hline 107 & Gagunin G & Diterpenoid & Phorbas sp. & $K-562^{a}$ & $\mathrm{LC}_{50} 2.0 \mu \mathrm{g} / \mathrm{mL}$ & [75] \\
\hline 108 & Gagunin H & Diterpenoid & Phorbas sp. & $K-562^{a}$ & $\mathrm{LC}_{50} 10.0 \mu \mathrm{g} / \mathrm{mL}$ & [76] \\
\hline 109 & Gagunin I & Diterpenoid & Phorbas sp. & $K-562^{a}$ & $\mathrm{LC}_{50} 11.5 \mu \mathrm{g} / \mathrm{mL}$ & [76] \\
\hline 110 & Gagunin J & Diterpenoid & Phorbas sp. & $\mathrm{K}-562^{\mathrm{a}}$ & $\mathrm{LC}_{50} 9.1 \mu \mathrm{g} / \mathrm{mL}$ & [76] \\
\hline 111 & Gagunin K & Diterpenoid & Phorbas sp. & $K-562^{a}$ & $\mathrm{LC}_{50} 17.5 \mu \mathrm{g} / \mathrm{mL}$ & [76] \\
\hline 112 & Gagunin L & Diterpenoid & Phorbas sp. & $\mathrm{K}-562^{\mathrm{a}}$ & $\mathrm{LC}_{50} 12.5 \mu \mathrm{g} / \mathrm{mL}$ & [76] \\
\hline 113 & Gagunin M & Diterpenoid & Phorbas sp. & $\mathrm{K}-562^{\mathrm{a}}$ & $\mathrm{LC}_{50} 0.71 \mu \mathrm{g} / \mathrm{mL}$ & [76] \\
\hline 114 & Gagunin N & Diterpenoid & Phorbas sp. & $K-562^{a}$ & $\mathrm{LC}_{50}>50 \mu \mathrm{g} / \mathrm{mL}$ & [76] \\
\hline 115 & Gagunin O & Diterpenoid & Phorbas sp. & $K-562^{a}$ & $\mathrm{LC}_{50} 11.1 \mu \mathrm{g} / \mathrm{mL}$ & [76] \\
\hline 116 & Gagunin P & Diterpenoid & Phorbas sp. & $K-562^{a}$ & $\mathrm{LC}_{50} 8.5 \mu \mathrm{g} / \mathrm{mL}$ & [76] \\
\hline 117 & Gagunin Q & Diterpenoid & Phorbas sp. & $\mathrm{K}-562^{\mathrm{a}}$ & $\mathrm{LC}_{50}>50 \mu \mathrm{g} / \mathrm{mL}$ & [76] \\
\hline \multirow[t]{2}{*}{118} & \multirow[t]{2}{*}{ Gukulenin A } & \multirow[t]{2}{*}{ tetraterpenoid } & \multirow[t]{2}{*}{$\begin{array}{c}\text { Phorbas } \\
\text { gukulensis }\end{array}$} & HCT-116 d & $\mathrm{IC}_{50} 62 \mathrm{nM}$ & [30] \\
\hline & & & & $\begin{array}{c}\text { FaDu }^{\mathrm{b}} \\
\text { SN12C } \\
\text { MKN45 } \\
\text { TOVG-21G }^{\mathrm{j}} \\
\text { OVCAR-3 }^{\mathrm{i}} \\
\text { A2780 }^{\mathrm{i}} \\
\text { SKOV3 }^{\mathrm{i}}\end{array}$ & 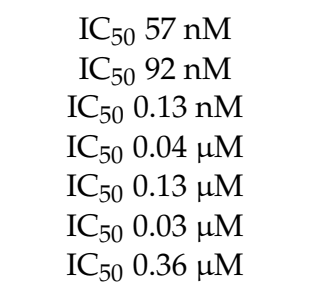 & [80] \\
\hline \multirow[t]{2}{*}{119} & \multirow[t]{2}{*}{ Gukulenin B } & \multirow[t]{2}{*}{ tetraterpenoid } & \multirow[t]{2}{*}{$\begin{array}{l}\text { Phorbas } \\
\text { gukulensis }\end{array}$} & HCT-116 d & $\mathrm{IC}_{50} 0.55 \mu \mathrm{M}$ & {$[30]$} \\
\hline & & & & $\begin{array}{l}\text { A2780 }{ }^{\mathrm{i}} \\
\text { FaDu }^{\mathrm{b}} \\
\mathrm{SN} 12 \mathrm{C}^{\mathrm{g}} \\
\text { MKN45 }\end{array}$ & $\begin{array}{ll}\mathrm{IC}_{50} & 0.63 \mu \mathrm{M} \\
\mathrm{IC}_{50} & 0.61 \mu \mathrm{M} \\
\mathrm{IC}_{50} & 0.72 \mu \mathrm{M}\end{array}$ & \\
\hline \multirow[t]{2}{*}{123} & \multirow[t]{2}{*}{ Gukulenin F } & \multirow[t]{2}{*}{ Tetraterpenoid } & \multirow[t]{2}{*}{$\begin{array}{c}\text { Phorbas } \\
\text { gukulensis }\end{array}$} & $K-562^{a}$ & $\mathrm{LC}_{50} 0.4 \mu \mathrm{M}$ & [30] \\
\hline & & & & $\begin{array}{l}\text { FaDu }{ }^{b} \\
\text { SN12C g } \\
\text { MKN45 j }\end{array}$ & $\begin{array}{ll}\mathrm{IC}_{50} & 0.63 \mu \mathrm{M} \\
\mathrm{IC}_{50} & 0.61 \mu \mathrm{M} \\
\mathrm{IC}_{50} & 0.72 \mu \mathrm{M}\end{array}$ & \\
\hline
\end{tabular}

${ }^{\mathrm{a}}$ leukemia; ${ }^{\mathrm{b}}$ pharynx carcinoma; ${ }^{\mathrm{c}}$ lung carcinoma; ${ }^{\mathrm{d}}$ colon carcinoma; ${ }^{\mathrm{e}}$ liver carcinoma; ${ }^{\mathrm{f}}$ pancreas carcinoma; ${ }^{\mathrm{g}}$ kidney carcinoma;

${ }^{\mathrm{h}}$ breast carcinoma; ${ }^{\mathrm{i}}$ ovarian cancer; ${ }^{j}$ gastric cancer.

\subsection{Cytotoxic and Cytostatic Activity}

Studies on the bioactivities of the metabolites isolated from sample of genus Phorbas mainly focus on the antiproliferative activity. For clarity and better reading purposes, data have been summarized in Table 1.

The alkaloid zarzissine (13) showed a potent cytotoxic activity against three cell lines: murine leukemia P-388, human nasopharyngeal carcinoma KB, and human lung carcinoma NSCLC-N6 [37].

Macrolides such as phorbasides A (20), C (22), D (23), and E (24) exert prominent cytotoxic effects against HCT-116 (human colon cancer cell line), demonstrated through in vitro assays. However, phorbaside B (21) showed no activity. These results suggest that the presence of the free hydroxyl group at $\mathrm{C}-2$ of the sugar moiety may play a key role in maintaining bioactivity [44]. Muironolide A (19) and phorboxazole A (17) are two other representative macrolides that possess cytotoxic activity against colon tumor cells [40] 
Among steroids, phorbasterones A-D (29-32) displayed moderate cytotoxicity toward HCT-116 cells [48]. More recently, the lipid fraction obtained from samples of P. amaranthus, likely enriched of sterols, was found to possess antiproliferative properties against HCT-116 cells [73].

The sesterterpenoids phorbaketals A-C (45-47) exhibited cytotoxic activity against human colorectal cancer HT-29, hepatoma cancer HepG2, and adenocarcinoma human alveolar basal epithelial cells lines A549, while phorbaketal N (50) was cytotoxic against human renal cancer cell lines A498 and ACHN and pancreatic cancer cell line PANC-1. Phorbaketal N (50) showed a better activity than the positive control molecule, fluorouracil. Studies on 50 and derivatives may be a path in the search for new treatments for pancreatic cancer [52,53]. Phorbaketal H-I (55-56), isolated from the sponge Monanchora sp., showed weak cytotoxicity against the human renal A498 cancer cell line. Considering structure-activity relationships, a ketone group at C-5 of ring A of phorbaketals is much more favorable than a hydroxy group for activity, and the hydroperoxy group in the side chain is harmful to the cytotoxicity [54].

The compound phorbin A (59), isolated from Monanchora sp., a possible precursor of several sesterterpenoids isolated for Phorbas, also showed moderate activity against renal human cancer cell lines ACHN and A498, and potent cytotoxicity against human pancreatic cancer cell lines PANC-1 and MIA-paca, similar to or better than the positive control, 5-fluorouracil [54].

In addition, the sesterterpenoids isosuberitenone B (84) and 19-suberitenone B (85) unveiled significant grow-inhibitory effects against A549, HepG2, HT-29, and MCF-7 tumor cell lines. In the same study, compounds suberitenone B (82), oxaspirosuberitenone (83), and isooxaspirosuberitenone (86) showed moderate activity against these same cell lines. These sesterterpenoids isolated from $P$. areolatus were also tested against Mia-Paca-2 (pancreatic cancer cell line), but showed no activity [67].

Putative anticancer lead compounds with a diterpenoid backbone were a) phorbasin B-C (88-89) and the terpenyl-taurine phorbasin E (91), tested in a colon cancer model (HCT116 cell line) [70] and b) gagunins A-Q (101-117) in K-562 cells (leukemia cell line) [75]. Among the latter, gagunins A and B (101-102) turned out to be the less active compounds. The authors suggest that the presence of a bulky group at C-11 of the five-membered ring negatively affects bioactivity, as compounds 107 and 108 are far less active than their congeners featuring either an acetoxyl group or hydrogen at the same position [75]. However, a synthetic gagunin A-derivative, in which the substituent groups placed on the three rings were replaced by hydroxyl groups, lacks activity [75].

The tetraterpenoid gukulenin B (119) exhibited significant cytotoxicity against human pharynx cell carcinoma line FaDu, gastric carcinoma cell MKN45, colon carcinoma cell line HCT-116, and renal carcinoma cell SN12C, and gukulenins C-F (120-123) showed potent cytotoxicity against K-562 and A549 cells [30]. Interestingly, gukulenin F (123) exhibited cytotoxicity against K-562 that was 17-fold more potent than doxorubicin, a positive control [30]. Moreover, gukulenin A (118) was shown to be a promising antitumor agent that (a) inhibited tumor growth in an ovarian cancer xenograft mouse model without any considerable adverse effect on their body weights, and (b) markedly reduced cell viability through apoptosis induction via the activation of caspases in four ovarian cancer cell lines. The cytotoxic activity of gukulenin A (118) is more potent than the positive control, cisplatin, in all ovarian cancer cells tested. This is the first report of an in vivo activity among compounds isolated from Phorbas [80].

Although several compounds showed promising results, cytotoxic studies on compounds from the genus Phorbas are, in most cases, at the initial phase. Only as recently as 2019 was there a study with gukulenin A (118) that advanced to in vivo studies using mouse models [80]. 


\subsection{Other Biological Activities}

Secondary metabolites isolated from sponges of the genus Phorbas displayed a large array of biological activities other than cytotoxicity (Table 2).

Anchinopeptolides B-D (2-4), peptide alkaloids from P. tenacior, exhibited high efficacy in displacing specific ligands from their relevant receptors: human B2 bradykinin, which has a high correlation with inflammation mediators by causing vasodilation, increasing vascular permeability, and stimulating the synthesis of prostaglandins; neuropeptide $Y$, which is involved in physiological and homeostatic processes such as vasoconstriction and growth of fat tissue; and somatostatin receptors, which belong to the $G$ protein class and have a wide expression pattern in both normal tissues and solid tumors [22,72,73]. On the other hand, anchinopeptolide A (1) was found to have weaker bioactivity in these binding assays [21]. The alkaloids zarzissine (13) and $p$-hydroxybenzaldehyde (14) showed slight antimicrobial activity against Staphylococcus aureus (gram-positive bacterium) and C. albicans and C. tropicalis (yeasts) [37].

The crude extract of Phorbas topsenti was reported to have high antioxidant activity in oxygen radical absorbance capacity (ORAC) assay, thereby leading to the isolation of phorbatopsins A-C (14-16), i.e., the compounds responsible for the observed radical scavenging activity. The antioxidant capacity of the isolated compounds was also evaluated with ORAC assay, measuring the loss of fluorescence of fluorescein in the presence of the oxidative species AAPH [2,2'-azobis(2-amidino-propane) dihydrochloride] and compared with Trolox ${ }^{\circledR}$, used as the positive control. Phorbatopsin A (14) was the most active substance, with an ORAC value comparable to Trolox ${ }^{\circledR}$. These data clearly indicate the importance of the $\mathrm{C} 5-\mathrm{C} 6$ double bond in compound $\mathbf{1 4}$ in improving the antioxidant properties of the phorbatopsin scaffold [26].

Macrolides phorboxazoles A-B (17-18) exhibited antifungal activity in the agar disc diffusion inhibition assay against Candida albicans and Saccharomyces carlsbergensis [24]. Another example is the macrolide muironolide A (19), which was reported to have antifungal activity against strains of Cryptococcus neoformans [81].

The genus Phorbas is also a source of other bioactive compounds, such the steroids amaroxocanes A-B (37-38), which were isolated and tested for chemical defense of the Caribbean coral reef sponge Phorbas amaranthus from fish predators. Amaroxocane B (38) showed significant deterrent activity ( $3 / 10$ pellets eaten), while amaroxocane A (37) elicited little feeding deterrence $(8 / 10$ pellets eaten) against a common reef predator, namely the bluehead wrasse. This study suggests that structural differences in the heterocycle moiety or the degree of sulfation may be responsible for differential anti-predatory activity [50].

Phorbaketal A (45), which also showed cytotoxic activity, can promote osteogenic differentiation of human mesenchymal stem cells, which exhibited increased levels of differentiation markers such as osteocalcin, Dlx5, ALP, Runx2, and TAZ after drug exposure. This compound showed potential for bone reformation processes and new anabolic therapeutics in bone diseases. Moreover, as inhibiting mesenchymal stem cells differentiate into adipocytes through a transcriptional coactivator with PDZ-binding motif, compound 45 may be a promising lead in designing novel drugs to treat obesity. In addition, this compound showed a promising dose dependent inhibition of inflammatory mediators via down-regulation of the NF- $\mathrm{kB}$ pathway and up-regulation of the HO-1 pathway [82-84]. The sesterterpenoids phorbasones A-B (76-77) promote calcium deposition in mensenchymal C3H10T1/2 cells, thus inducing osteoblast differentiation. The authors concluded that phorbasone A (76) showed a distinct calcium deposition effect as compared to phorbasone B (77). Particularly, gene expression analysis of osteoblast differentiation markers revealed that compound 76 increases Runx2 (a Runt protein), ALP (alkaline phosphatase), OSX (osterix), PTH (parathyroid hormone), and PTHrP (PTHrelated peptide) mRNA [65]. Another study reported on the potent inhibitory activity on nitric oxide (NO) production in RAW 264.7 LPS-activated mouse macrophage cells by phorbasone A acetate (79). This result indicated that effective suppression of NO production is a valuable strategy for the discovery of anti-inflammatory compounds [65]. 
Among sesterterpenoids, suberitenones A and B, oxaspirosuberitenone, isosuberitenone B, 19-episuberitenone B, and isooxaspirosuberitenone (81-86), isolated from Phorbas areolatus (non-polar fraction), were tested against gram positive (methicillin resistant and methicillin sensitive Staphylococcus aureus, MRSA, and MSSA) and gram negative (Escherichia coli, and Klebsiella pneumoniae) bacteria. This study reported oxaspirosuberitenone (83) as a significant antimicrobial compound against MRSA at the highest concentration tested $[67,85]$.

Table 2. List of MNPs originated from Phorbas with biological activities.

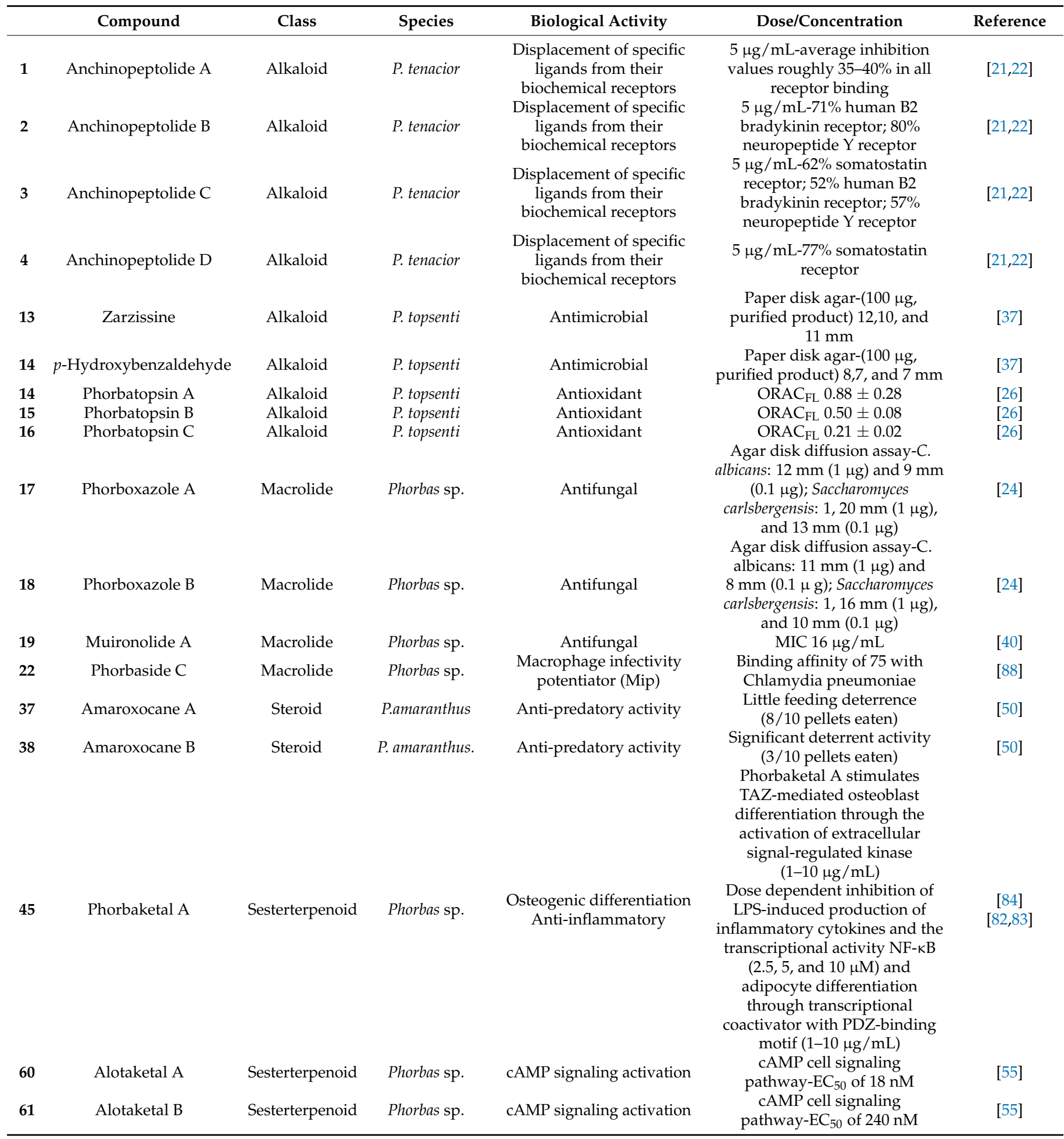


Table 2. Cont.

\begin{tabular}{|c|c|c|c|c|c|c|}
\hline & Compound & Class & Species & Biological Activity & Dose/Concentration & Reference \\
\hline 62 & Alotaketal C & Sesterterpenoid & Phorbas sp. & $\begin{array}{l}\text { Latency-reversing agent } \\
\text { (LRA) }\end{array}$ & $\begin{array}{l}\text { HIV-1 provirus / GFP expression } \\
\text { of J-Lat } 9.2 \text { cells- } 1 \mu \mathrm{M}\end{array}$ & {$[56,57,78]$} \\
\hline 63 & Alotaketal D & Sesterterpenoid & Phorbas sp. & $\begin{array}{l}\text { Latency-reversing agent } \\
\text { (LRA) }\end{array}$ & $\begin{array}{l}\text { HIV-1 provirus/GFP expression } \\
\text { of J-Lat } 9.2 \text { cells- } 30 \mu \mathrm{M}\end{array}$ & {$[56,57,78]$} \\
\hline 65 & Ansellone A & Sesterterpenoid & Phorbas sp. & $\begin{array}{l}\text { cAMP signaling activation } \\
\text { Latency-reversing agent } \\
\text { (LRA)cAMP activator }\end{array}$ & $\begin{array}{c}\text { cAMP cell signaling } \\
\text { pathway-EC } 50 \text { of } 14 \mu \mathrm{M} \\
\text { HIV-1 provirus /GFP expression } \\
\text { of J-Lat } 9.2 \text { cells- } 30 \mu \mathrm{M}\end{array}$ & {$[57,62]$} \\
\hline 66 & Ansellone B & Sesterterpenoid & Phorbas sp. & $\begin{array}{l}\text { Inhibition of inducible } \\
\text { NOS (iNOS) }\end{array}$ & $\begin{array}{c}\text { RAW 264.7 LPS-activated mouse } \\
\text { macrophage cells-IC } \mathrm{C}_{50}=\mathrm{f} \\
4.5 \mu \mathrm{M},\end{array}$ & [66] \\
\hline 73 & Anvilone A & Sesterterpenoid & Phorbas sp. & $\begin{array}{l}\text { Latency-reversing agent } \\
\text { (LRAs) }\end{array}$ & $\begin{array}{l}\text { HIV-1 provirus / GFP expression } \\
\text { of J-Lat } 9.2 \text { cells- } 30 \mu \mathrm{M}\end{array}$ & [57] \\
\hline 76 & Phorbasone A & Sesterterpenoid & Phorbas sp. & Osteogenic properties & $\begin{array}{l}\text { Calcium deposition effect at a } \\
\text { concentration of } 0.5 \mu \mathrm{g} / \mathrm{mL}\end{array}$ & [65] \\
\hline 79 & Phorbasone A acetate & Sesterterpenoid & Phorbas sp. & $\begin{array}{l}\text { Inhibition of inducible } \\
\text { NOS (iNOS) }\end{array}$ & $\begin{array}{l}\text { Inhibitory activity on NOS in } \\
\text { RAW 264.7 LPS-activated mouse } \\
\text { macrophage cells-IC } \text { I }_{50}=2.8 \mu \mathrm{M}\end{array}$ & [66] \\
\hline 83 & Oxaspirosuberitenone & Sesterterpenoids & P. areolatus & Antimicrobial & $\begin{array}{l}\text { Activity against MRSA at the } \\
\text { highest concentration tested } \\
(160 \mu \mathrm{M})\end{array}$ & [67] \\
\hline 94 & Phorbasin H & Diterpenoid & Phorbas sp. & Antifungal & $\begin{array}{l}\text { Suppression of the hyphal } \\
\text { development of C. albicans } \\
(250 \mu \mathrm{g} / \mathrm{mL})\end{array}$ & [86] \\
\hline $\begin{array}{l}93- \\
95\end{array}$ & Phorbasins & Diterpenoid & Phorbas sp. & Antifungal & $\begin{array}{c}\text { EtOH extract-growth inhibitory } \\
\text { activity against the } \\
\text { gram-positive bacteria } \\
\text { Staphylococcus aureus and } \\
\text { Micrococcus } \\
\text { luteus-Concentration: N/A }\end{array}$ & {$[68,69]$} \\
\hline 104 & Gagunin D & Diterpenoid & Phorbas sp. & Anti-melanogenic & $\begin{array}{c}\mathrm{IC}_{50}=5.7 \mu \mathrm{g} / \mathrm{mL} ; 10 \mu \mathrm{M} \text { on } \\
\mathrm{UVB} \text { irradiated human skin } \\
\text { models demonstrated a } \\
\text { considerable reduction melanin } \\
\text { biosynthesis }\end{array}$ & [87] \\
\hline $\begin{array}{l}101- \\
117\end{array}$ & Gagunins & Diterpenoid & Phorbas sp. & $\begin{array}{l}\text { Isocitrate lyase (ICL) } \\
\text { inhibition }\end{array}$ & $\mathrm{LC}_{50}$ of $55-140 \mu \mathrm{g} / \mathrm{mL}$ & [76] \\
\hline 125 & Astaxanthin & Carotenoid & P. topsenti & Antioxidant & $\mathrm{ORAC}_{\mathrm{FL}} 0.22 \pm 0.02$ & [26] \\
\hline 126 & Adonirubin & Carotenoid & P. topsenti & Antioxidant & $\mathrm{ORAC}_{\mathrm{FL}} 0.024 \pm 0.001$ & [26] \\
\hline 127 & Taurine & Sulfonic acid & P. topsenti & Antioxidant & ORAC $_{\mathrm{FL}} 0.083 \pm 0.013$ & [26] \\
\hline 128 & Taurobetaine & Sulfonic acid & P. topsenti & Antioxidant & $\mathrm{ORAC}_{\mathrm{FL}} 00.019 \pm 0.002$ & [26] \\
\hline
\end{tabular}

Ansellone A (65) can activate cAMP signaling in HEK293 cells, derived from human embryonic kidney cells grown in a tissue culture, which is a very important technique for the development of treatments for several diseases such as heart failure, cancer, and neurodegenerative diseases. cAMP signaling activation by ansellone A (65) was comparable to that of forskolin, a natural product used for the treatment of cancer, obesity, and allergies [56]. The latency reversal activity (LRA) of 65, which has the function of reactivating the virus production in infected cells and producing an immune response or cell death, was also reported and determined by quantification of the changes in intracellular GFP expression in microplate [64]. The sesterterpenoid ansellone B (66) was reported as a potent inhibitor on nitric oxide production in RAW 264.7 LPS-activated mouse macrophage cells [59].

Alotaketals A and B (60-61) have also been reported for the activation of the cAMP cell signaling pathway. In addition, the compounds alotaketal C (62) and D (63) and anvilone A (74) were reported to activate the latent proviral HIV-1 gene expression. Notably, alotaketal $\mathrm{C}$ (62) was more potent and gave a stronger effect than the control compound prostratin at the same concentration, while alotaketal D (63) and anvilone A (74) elicited similar responses as prostratin $[52,54,77,78]$. The diterpen phorbasin $\mathrm{H}$ (94) was reported as an inhibitor of the yeast-to-hypha transition in Candida albicans. Growth experiments suggested that this compound does not inhibit yeast cell growth but inhibits filamentous 
growth in C. albicans, which means that the phorbasin $\mathrm{H}$ (94) induces a change in $C$. albicans morphology [86]. Another study reported the ethanolic extract rich in phorbasins (87-89) from the Phorbas sp. could exert growth inhibitory activity against gram positive bacteria, such as Staphylococcus aureus and Micrococcus luteus. It was not possible to test pure compounds due to the low amount available and their instability $[31,68]$.

One study concerning the cosmetic use of gagunin D (104) identified this compound as a potential anti-melanogenic agent. Gagunin D (104) inhibited the synthesis of melanin in both mouse melan-a cells and a reconstructed human skin model. Suppression of tyrosinase expression and increased rate of tyrosinase degradation as well as inhibition of its enzymatic activity are putative mechanisms underlying the anti-melanogenic activity exhibited by gagunin D (104). These studies highlight the potential use of gagunin D (104) for skin lightening cosmetic formulations [87].

The summary of these biological activities reported for compounds isolated from extracts of the genus Phorbas sp. are found in Table 2.

As can be seen, most of the assays were carried out in vitro and obtained very promising results. Thus, more robust studies and in vivo assays of these substances must be carried out to prove their effectiveness against the various diseases previously tested in these studies.

\section{Conclusions}

Marine sponges, including Phorbas, still represent a prolific source of new molecules yet to be discovered. Novel and more powerful tools should be developed to (a) ameliorate and accelerate the discovery process and (b) reduce the risk of re-discovery of MNPs. Dereplication based upon liquid chromatography coupled with high-resolution tandem mass spectrometry is a well-suited approach to solve these issues and allow detection of new metabolites, even from well-known sponges such as Phorbas. In this regard, molecular networking $[89,90]$ could represent a suitable means for (a) fast detection, annotation, and visualization of known compounds and their novel analogues and (b) an in-depth re-examination of Phorbas species to unlock overlooked chemical entities. A fundamental aspect in bioactive natural products research is certainly the assignment of stereochemistry to identify the pharmacophore of a molecule and investigate drug-target interaction. Due to the limited amounts of available compound, elucidation of the stereochemistry of natural products is very challenging. Therefore, as shown for many metabolites from natural sources, including Phorbas sponges, chemical degradation of a molecule into simpler compounds can be exploited as a valuable approach to assist spectroscopic analysis in the assignment of relative and absolute configuration of natural products.

This article provides a comprehensive review of the literature on sponges of the genus Phorbas, throughout 1993-2020, and summarizes the discovery of one hundred and thirty-two compounds, including alkaloids, macrolides, terpenoids, and steroids, and a brief insight into the putative biogenetic pathway and biosynthetic origin of sesterterpenoids from Phorbas sponges. Moreover, this review includes a survey on pharmacological activities shown by the reported metabolites.

Cytotoxic activity displayed by secondary metabolites from this genus make them interesting MNPs for development of new drugs with antineoplastic activity. Thus, this article aims to be useful for the bioprospecting process of marine sponges of the genus Phorbas and to bring attention to its biochemical diversity.

Author Contributions: Conceptualization, V.C. and R.C.C.M.; resources, A.C., G.E., F.B.d.S., L.P.A.N.C.; data curation, A.C., G.D.S.; writing-original draft preparation, A.C., G.E., F.B.d.S., L.P.A.N.C.; writing-review and editing, A.C., G.D.S., R.T., V.C.; supervision, V.C., R.C.C.M., A.L.V.; funding acquisition, V.C. All authors have read and agreed to the published version of the manuscript.

Funding: This research was funded by Bando contributo alla ricerca, Anno 2021: Progetto "CiaAQ", PI Valeria Costantino, The Agency for the Improvement of Higher Education Personnel (CAPES) [Finance Code 001], and The National Council for Scientific and Technological Development (CNPq) [grant number 406064/2018-0 and the scholarship 108553/2017-5]. 
Institutional Review Board Statement: Not applicable.

Informed Consent Statement: Not applicable.

Conflicts of Interest: The authors declare no conflict of interest.

\section{References}

1. Esposito, G.; Della Sala, G.; Teta, R.; Caso, A.; Bourguet-Kondracki, M.L.; Pawlik, J.R.; Mangoni, A.; Costantino, V. Chlorinated Thiazole-Containing Polyketide-Peptides from the Caribbean Sponge Smenospongia conulosa: Structure elucidation on microgram scale. Eur. J. Org. Chem. 2016, 2016, 2871-2875. [CrossRef]

2. Britstein, M.; Devescovi, G.; Handley, K.M.; Malik, A.; Haber, M.; Saurav, K.; Teta, R.; Costantino, V.; Burgsdorf, I.; Gilbert, J.A.; et al. A new N-Acyl homoserine lactone synthase in an uncultured symbiont of the red sea sponge Theonella swinhoei. Appl. Environ. Microbiol. 2016, 82, 1274-1285. [CrossRef]

3. Carroll, A.R.; Copp, B.R.; Davis, R.A.; Keyzers, R.A.; Prinsep, M.R. Marine natural products. Nat. Prod. Rep. 2020, $37,175-223$. [CrossRef]

4. Varijakzhan, D.; Loh, J.Y.; Yap, W.S.; Yusoff, K.; Seboussi, R.; Lim, S.H.E.; Lai, K.S.; Chong, C.M. Bioactive compounds from marine sponges: Fundamentals and applications. Mar. Drugs 2021, 19, 246. [CrossRef]

5. Thomas, T.; Moitinho-Silva, L.; Lurgi, M.; Björk, J.R.; Easson, C.; Astudillo-García, C.; Olson, J.B.; Erwin, P.M.; López-Legentil, S.; Luter, H.; et al. Diversity, structure and convergent evolution of the global sponge microbiome. Nat. Commun. 2016, 7, 11870. [CrossRef]

6. Della Sala, G.; Hochmuth, T.; Costantino, V.; Teta, R.; Gerwick, W.; Gerwick, L.; Piel, J.; Mangoni, A. Polyketide genes in the marine sponge Plakortis simplex: A new group of mono-modular type I polyketide synthases from sponge symbionts. Environ. Microbiol. Rep. 2013, 5, 809-818. [CrossRef]

7. Pita, L.; Rix, L.; Slaby, B.M.; Franke, A.; Hentschel, U. The sponge holobiont in a changing ocean: From microbes to ecosystems. Microbiome 2018, 6, 46. [CrossRef]

8. Lemloh, M.-L.; Fromont, J.; Brümmer, F.; Usher, K.M. Diversity and abundance of photosynthetic sponges in temperate Western Australia. BMC Ecol. 2009, 9, 4. [CrossRef]

9. Esposito, G.; Teta, R.; Marrone, R.; De Sterlich, C.; Casazza, M.; Anastasio, A.; Lega, M.; Costantino, V. A fast detection strategy for Cyanobacterial blooms and associated cyanotoxins (FDSCC) reveals the occurrence of lyngbyatoxin A in Campania (South Italy). Chemosphere 2019, 225, 342-351. [CrossRef]

10. Teta, R.; Della Sala, G.; Esposito, G.; Stornaiuolo, M.; Scarpato, S.; Casazza, M.; Anastasio, A.; Lega, M.; Costantino, V. Monitoring cyanobacterial blooms during the COVID-19 pandemic in Campania, Italy: The case of lake avernus. Toxins 2021, $13,471$. [CrossRef]

11. Teta, R.; Irollo, E.; Della Sala, G.; Pirozzi, G.; Mangoni, A.; Costantino, V. Smenamides A and B, chlorinated peptide/polyketide hybrids containing a dolapyrrolidinone unit from the Caribbean sponge Smenospongia aurea. Evaluation of their role as leads in antitumor drug research. Mar. Drugs 2013, 11, 4451-4463. [CrossRef]

12. Caso, A.; Esposito, G.; Della Sala, G.; Pawlik, J.R.; Teta, R.; Mangoni, A.; Costantino, V. Fast detection of two smenamide family members using molecular networking. Mar. Drugs 2019, 17, 618. [CrossRef] [PubMed]

13. Saurav, K.; Borbone, N.; Burgsdorf, I.; Teta, R.; Caso, A.; Bar-Shalom, R.; Esposito, G.; Britstein, M.; Steindler, L.; Costantino, V. Identification of quorum sensing activators and inhibitors in the marine sponge Sarcotragus spinosulus. Mar. Drugs 2020, 18, 127. [CrossRef]

14. Elgoud Said, A.A.; Mahmoud, B.K.; Attia, E.Z.; Abdelmohsen, U.R.; Fouad, M.A. Bioactive natural products from marine sponges belonging to family Hymedesmiidae. RSC Adv. 2021, 11, 16179-16191. [CrossRef]

15. Woolly, E.F.; Singh, A.J.; Russell, E.R.; Miller, J.H.; Northcote, P.T. Hamigerans R and S: Nitrogenous Diterpenoids from the New Zealand marine sponge Hamigera tarangaensis. J. Nat. Prod. 2018, 81, 387-393. [CrossRef] [PubMed]

16. Thacker, R.W.; Hill, A.L.; Hill, M.S.; Redmond, N.E.; Collins, A.G.; Morrow, C.C.; Spicer, L.; Carmack, C.A.; Zappe, M.E.; Pohlmann, D.; et al. Nearly complete $28 \mathrm{~S}$ rRNA gene sequences confirm new hypotheses of sponge evolution. Integr. Comp. Biol. 2013, 53, 373-387. [CrossRef] [PubMed]

17. Evcen, A.; Çinar, M.E.; Zengin, M.; Süer, S.; Rüzgar, M. New records of five sponge species (Porifera) for the Black Sea. Zootaxa 2016, 4103, 267-275. [CrossRef]

18. Huguenin, L.; Salani, S.; Lopes, M.F.; Albano, R.M.; Hajdu, E.; Esteves, E.L. Integrative taxonomy of hemimycale (hymedesmiidae: Poecilosclerida: Demospongiae) from southeastern Brazil, with the description of two new species. Zootaxa 2018, 4442, 137-152. [CrossRef]

19. Angulo-Preckler, C.; Cid, C.; Oliva, F.; Avila, C. Antifouling activity in some benthic Antarctic invertebrates by "in situ" experiments at Deception Island, Antarctica. Mar. Environ. Res. 2015, 105, 30-38. [CrossRef] [PubMed]

20. Koutsouveli, V.; Taboada, S.; Moles, J.; Cristobo, J.; Ríos, P.; Bertran, A.; Solà, J.; Avila, C.; Riesgo, A. Insights into the reproduction of some Antarctic dendroceratid, poecilosclerid, and haplosclerid demosponges. PLoS ONE 2018, 13, e192267. [CrossRef]

21. Casapullo, A.; Finamore, E.; Minale, L.; Zollo, F. A dimeric peptide alkaloid of a completely new type, Anchinopeptolide A, from the marine sponge Anchinoe tenacior. Tetrahedron Lett. 1993, 34, 6297-6300. [CrossRef] 
22. Casapullo, A.; Minale, L.; Zollo, F.; Lavayre, J. Four new dimeric peptide alkaloids, anchinopeptolides B-D, and cycloanchinopeptolide C, congeners of anchinopeptolide A, from the mediterranean marine sponge Anchinoe tenacior. J. Nat. Prod. 1994, 57, 1227-1233. [CrossRef]

23. Rudi, A.; Stein, Z.; Green, S.; Goldberg, I.; Kashman, Y.; Benayahu, Y.; Schleyer, M. Phorbazoles A-D, novel chlorinated phenylpyrrolyloxazoles from the marine sponge Phorbas aff. clathrata. Tetrahedron Lett. 1994, 35, 2589-2592. [CrossRef]

24. Searle, P.A.; Molinski, T.F. Phorboxazoles A and B: Potent cytostatic macrolides from marine sponge Phorbas Sp. J. Am. Chem. Soc. 1995, 117, 8126-8131. [CrossRef]

25. Dalisay, D.S.; Molinski, T.F. Structure elucidation at the nanomole scale. 2. Hemi-phorboxazole A from Phorbas sp. +. Org. Lett. 2009, 11, 1967-1970. [CrossRef] [PubMed]

26. Nguyen, T.D.; Nguyen, X.C.; Longeon, A.; Keryhuel, A.; Le, M.H.; Kim, Y.H.; Chau, V.M.; Bourguet-Kondracki, M.L. Antioxidant benzylidene 2-aminoimidazolones from the Mediterranean sponge Phorbas topsenti. Tetrahedron 2012, 68, 9256-9259. [CrossRef]

27. Morinaka, B.I.; Masuno, M.N.; Pawlik, J.R.; Molinski, T.F. Amaranzole A, a new N-imidazolyl steroid from Phorbas amaranthus. Org. Lett. 2007, 9, 5219-5222. [CrossRef] [PubMed]

28. Morinaka, B.I.; Pawlik, J.R.; Molinski, T.F. Amaranzoles B-F, imidazole-2-carboxy steroids from the marine sponge Phorbas amaranthus. C24-N- And C24- O -analogues from a divergent oxidative biosynthesis. J. Org. Chem. 2010, 75, 2453-2460. [CrossRef] [PubMed]

29. Park, S.Y.; Choi, H.; Hwang, H.; Kang, H.; Rho, J.R. Gukulenins A and B, cytotoxic tetraterpenoids from the marine sponge Phorbas gukulensis. J. Nat. Prod. 2010, 73, 734-737. [CrossRef]

30. Jeon, J.E.; Liao, L.; Kim, H.; Sim, C.J.; Oh, D.C.; Oh, K.B.; Shin, J. Cytotoxic diterpenoid pseudodimers from the Korean sponge Phorbas gukhulensis. J. Nat. Prod. 2013, 76, 1679-1685. [CrossRef]

31. Vuong, D.; Capon, R.J. Phorbasin A: A novel diterpene from a southern Australian marine sponge, Phorbas species. J. Nat. Prod. 2000, 63, 1684-1685. [CrossRef]

32. Bastos Lemos Silva, S.; Beniddir, M.A.; Gallard, J.F.; Poupon, E.; Thomas, O.P.; Evanno, L. Chemical Insights into the Anchinopeptolide Series. Eur. J. Org. Chem. 2019, 2019, 5515-5518. [CrossRef]

33. Casapullo, A.; Minale, L.; Zollo, F. The unique 6-(p-hydroxyphenyl)-2H-3,4-dihydro-1,1-dioxo-1,4-thiazine and the new tripeptide l-glu-gly-4-hydroxystirylamine from the marine sponge Anchinoe tenacior. Tetrahedron Lett. 1994, 35, 2421-2422. [CrossRef]

34. Nuzzo, G.; Ciavatta, M.L.; Kiss, R.; Mathieu, V.; Leclercqz, H.; Manzo, E.; Villani, G.; Mollo, E.; Lefranc, F.; D’Souza, L.; et al. Chemistry of the nudibranch Aldisa andersoni: Structure and biological activity of phorbazole metabolites. Mar. Drugs 2012, 10, 1799-1811. [CrossRef]

35. Guttormsen, Y.; Fairhurst, M.E.; Pandey, S.K.; Isaksson, J.; Haug, B.E.; Bayer, A. Total synthesis of phorbazole B. Molecules 2020, 25, 4848. [CrossRef]

36. Radspieler, A.; Liebscher, J. Total synthesis of phorbazole C. Tetrahedron 2001, 57, 4867-4871. [CrossRef]

37. Bouaicha, N.; Amade, P.; Fuel, D.; Roussakis, C. Zarzissine, a new cytotoxic guanidine alkaloid from the mediterranean sponge Anchinoe paupertas. J. Nat. Prod. 1994, 57, 1455-1457. [CrossRef]

38. Vacelet, J.; Perez, T. Phorbas topsenti and Phorbas tailliezi (Demospongiae, Poecilosclerida), new names for the Mediterranean "Phorbas paupertas" and "Phorbas coriaceus". Zootaxa 2008, 1873, 26-38. [CrossRef]

39. Moyna, G.; Manta, E. Conformational analysis of phorboxazole bis-oxazole oxane fragment analogs by NMR spectroscopy and molecular modeling simulations. Magn. Reson. Chem. 2008, 46, 36-41.

40. Dalisay, D.S.; Morinaka, B.I.; Skepper, C.K.; Molinski, T.F. A tetrachloro polyketide hexahydro-1H-isoindolone, muironolide A, from the marine sponge Phorbas sp. natural products at the nanomole scale. J. Am. Chem. Soc. 2009, 131, 7552-7553. [CrossRef]

41. Zampella, A.; D'Auria, M.V.; Minale, L.; Debitus, C.; Roussakis, C. Callipeltoside A: A cytotoxic aminodeoxy sugar-containing macrolide of a new type from the marine Lithistida sponge Callipelta sp. J. Am. Chem. Soc. 1996, 118, 11085. [CrossRef]

42. Costantino, V.; Fattorusso, E.; Imperatore, C.; Mangoni, A.; Teta, R. Terpioside from the marine sponge Terpios sp., the first glycosphingolipid having an L-fucofuranose unit. Eur. J. Org. Chem. 2008, 2130-2134. [CrossRef]

43. Costantino, V.; Fattorusso, E.; Imperatore, C.; Mangoni, A.; Teta, R. Amphiceramide A and B, novel glycosphingolipids from the marine sponge Amphimedon compressed. Eur. J. Org. Chem. 2009, 13, 2112-2119. [CrossRef]

44. MacMillan, J.B.; Guang, X.Z.; Skepper, C.K.; Molinski, T.F. Phorbasides A-E, cytotoxic chlorocyclopropane macrolide glycosides from the marine sponge Phorbas sp. CD determination of C-methyl sugar configurations. J. Org. Chem. 2008, 73, 3699-3706. [CrossRef] [PubMed]

45. Paterson, I.; Paquet, T. Total synthesis and configurational validation of (+)-phorbaside A. Org. Lett. 2010, 12, $2158-2161$. [CrossRef] [PubMed]

46. Dalisay, D.S.; Molinski, T.F. NMR quantitation of natural products at the nanomole scale. J. Nat. Prod. 2009, 72, 739-744. [CrossRef]

47. Dalisay, D.S.; Molinski, T.F. Structure elucidation at the nanomole scale. 3. phorbasides G-I from Phorbas sp. J. Nat. Prod. 2010, 73, 679-682. [CrossRef] [PubMed]

48. Masuno, M.N.; Pawlik, J.R.; Molinski, T.F. Phorbasterones A-D, Cytotoxic Nor-Ring A Steroids from the Sponge Phorbas amaranthus. J. Nat. Prod. 2004, 67, 731-733. [CrossRef]

49. Tischler, M.; Ayer, S.W.; Andersen, R.J.; Mitchell, J.F.; Clardy, J. Anthosterones A and B, ring A contracted steroids from the sponge Anthoracuata graceae. Can. J. Chem. 1988, 66, 1173-1178. [CrossRef] 
50. Morinaka, B.I.; Pawlik, J.R.; Molinski, T.F. Amaroxocanes A and B: Sulfated dimeric sterols defend the caribbean coral reef sponge Phorbas amaranthus from fish predators. J. Nat. Prod. 2009, 72, 259-264. [CrossRef] [PubMed]

51. Nahar, L.; Sarker, S.D. Steroid Dimers; Wiley: Hoboken, NJ, USA, 2012; ISBN 9781119972853.

52. Rho, J.R.; Hwang, B.S.; Sim, C.J.; Joung, S.; Lee, H.Y.; Kim, H.J. Phorbaketals A, B, and C, sesterterpenoids with a spiroketal of hydrobenzopyran moiety isolated from the marine sponge Phorbas sp. Org. Lett. 2009, 11, 5590-5593. [CrossRef] [PubMed]

53. Lee, Y.; Wang, W.; Kim, H.; Giri, A.G.; Won, D.H.; Hahn, D.; Baek, K.R.; Lee, J.; Yang, I.; Choi, H.; et al. Phorbaketals L-N, cytotoxic sesterterpenoids isolated from the marine sponge of the genus Phorbas. Bioorganic Med. Chem. Lett. 2014, 24, 4095-4098. [CrossRef] [PubMed]

54. Wang, W.; Mun, B.; Lee, Y.; Reddy, M.V.; Park, Y.; Lee, J.; Kim, H.; Hahn, D.; Chin, J.; Ekins, M.; et al. Bioactive sesterterpenoids from a Korean sponge Monanchora sp. J. Nat. Prod. 2013, 76, 170-177. [CrossRef] [PubMed]

55. Forestieri, R.; Merchant, C.E.; De Voogd, N.J.; Matainaho, T.; Kieffer, T.J.; Andersen, R.J. Alotaketals A and B, sesterterpenoids from the marine sponge hamigera species that activate the camp cell signaling pathway. Org. Lett. 2009, 11, 5166-5169. [CrossRef]

56. Daoust, J.; Chen, M.; Wang, M.; Williams, D.E.; Chavez, M.A.G.; Wang, Y.A.; Merchant, C.E.; Fontana, A.; Kieffer, T.J.; Andersen, R.J. Sesterterpenoids isolated from a northeastern pacific Phorbas sp. J. Org. Chem. 2013, 78, 8267-8273. [CrossRef]

57. Wang, M.; Tietjen, I.; Chen, M.; Williams, D.E.; Daoust, J.; Brockman, M.A.; Andersen, R.J. Sesterterpenoids isolated from the Sponge Phorbas sp. activate latent HIV-1 provirus expression. J. Org. Chem. 2016, 81, 11324-11334. [CrossRef] [PubMed]

58. Zhang, F.M.; Zhang, S.Y.; Tu, Y.Q. Recent progress in the isolation, bioactivity, biosynthesis, and total synthesis of natural spiroketals. Nat. Prod. Rep. 2018, 35, 75-104. [CrossRef]

59. Cheng, H.; Zhang, Z.; Yao, H.; Zhang, W.; Yu, J.; Tong, R. Unified asymmetric total syntheses of (-)-Alotaketals A-D and (-)-Phorbaketal A. Angew. Chem. 2017, 129, 9224-9228. [CrossRef]

60. Lee, J.; Kim, J.; Lee, H.Y. Au(I)-Catalyzed Cyclization of epoxyalkynes to allylic alcohol containing spiroketals and application to the total synthesis of (-)-Alotaketal A. Org. Lett. 2020, 22, 4073-4077. [CrossRef]

61. Yao, H.; Zhou, N.; Zhang, Z.; Guan, W.; Wang, H.; Cheng, H. Recent developments in syntheses of alotaketals and phorbaketals. Tetrahedron Lett. 2020, 61, 151480. [CrossRef]

62. Daoust, J.; Fontana, A.; Merchant, C.E.; De Voogd, N.J.; Patrick, B.O.; Kieffer, T.J.; Andersen, R.J. Ansellone A, a sesterterpenoid isolated from the nudibranch cadlina luteromarginata and the sponge Phorbas sp., activates the cAMP signaling pathway. Org. Lett. 2010, 12, 3208-3211. [CrossRef]

63. Zhang, W.; Yao, H.; Yu, J.; Zhang, Z.; Tong, R. Total syntheses of Sesterterpenoid ansellones A and B, and Phorbadione. Angew. Chem. Int. Ed. 2017, 56, 4787-4791. [CrossRef] [PubMed]

64. Yanagihara, M.; Murai, K.; Kishimoto, N.; Abe, T.; Misumi, S.; Arisawa, M. Total synthesis and biological evaluation of the potent HIV latency-reversing agent Ansellone A and its analogues. Org. Lett. 2021, 23, 1720-1725. [CrossRef] [PubMed]

65. Rho, J.R.; Hwang, B.S.; Joung, S.; Byun, M.R.; Hong, J.H.; Lee, H.Y. Phorbasones A and B, sesterterpenoids isolated from the marine sponge Phorbas sp. and induction of osteoblast differentiation. Org. Lett. 2011, 13, 884-887. [CrossRef] [PubMed]

66. Wang, W.; Lee, Y.; Lee, T.G.; Mun, B.; Giri, A.G.; Lee, J.; Kim, H.; Hahn, D.; Yang, I.; Chin, J.; et al. Phorone A and isophorbasone A, sesterterpenoids isolated from the marine sponge Phorbas sp. Org. Lett. 2012, 14, 4486-4489. [CrossRef] [PubMed]

67. Solanki, H.; Angulo-Preckler, C.; Calabro, K.; Kaur, N.; Lasserre, P.; Cautain, B.; de la Cruz, M.; Reyes, F.; Avila, C.; Thomas, O.P. Suberitane sesterterpenoids from the Antarctic sponge Phorbas areolatus (Thiele, 1905). Tetrahedron Lett. 2018, 59, $3353-3356$. [CrossRef]

68. McNally, M.; Capon, R.J. Phorbasin B and C: Novel diterpenes from a Southern Australian marine sponge, Phorbas species. J. Nat. Prod. 2001, 64, 645-647. [CrossRef]

69. Macklin, T.K.; Micalizio, G.C. Total synthesis and structure elucidation of (+)-phorbasin C. J. Am. Chem. Soc. 2009, 131, 1392-1393. [CrossRef]

70. Zhang, H.; Capon, R.J. Phorbasins D-F: Diterpenyl-taurines from a Southern Australian marine sponge, Phorbas sp. Org. Lett. 2008, 10, 1959-1962. [CrossRef]

71. Lee, H.S.; Park, S.Y.; Sim, C.J.; Rho, J.R. Phorbasins G-I: Three new diterpenoids from the sponge Phorbas gukulensis. Chem. Pharm. Bull. 2008, 56, 1198-1200. [CrossRef]

72. Takahashi, K.; Ogura, Y.; Kuse, M.; Takikawa, H. First synthesis and absolute configuration of phorbasin H, a diterpene carboxylic acid isolated from the sponge Phorbas gukulensis. Biosci. Biotechnol. Biochem. 2019, 83, 2198-2201. [CrossRef]

73. Do Amaral, B.S.; da Silva, F.B.; Leme, G.M.; Schmitz, L.S.S.; Jimenez, P.C.; Martins, R.C.C.; Cass, Q.B.; Valverde, A.L. Integrated analytical workflow for chromatographic profiling and metabolite annotation of a cytotoxic Phorbas amaranthus extract. J. Chromatogr. B Anal. Technol. Biomed. Life Sci. 2021, 1174, 122720. [CrossRef] [PubMed]

74. Zhang, H.; Major, J.M.; Lewis, R.J.; Capon, R.J. Phorbasins G-K: New cytotoxic diterpenes from a southern Australian marine sponge, Phorbas sp. Org. Biomol. Chem. 2008, 6, 3811-3815. [CrossRef] [PubMed]

75. Rho, J.R.; Lee, H.S.; Sim, C.J.; Shin, J. Gagunins, highly oxygenated diterpenoids from the sponge Phorbas sp. Tetrahedron 2002, 58, 9585-9591. [CrossRef]

76. Kyoung, H.J.; Jeon, J.E.; Ryu, S.; Lee, H.S.; Oh, K.B.; Shin, J. Polyoxygenated diterpenes from the sponge Phorbas sp. J. Nat. Prod. 2008, 71, 1701-1707. [CrossRef] 
77. Tymann, D.; Bednarzick, U.; Iovkova-Berends, L.; Hiersemann, M. Progress toward the Total Synthesis of Gukulenin A: Photochemically Triggered Two-Carbon Ring Expansion Key to $\alpha$-Tropolonic Ether Synthesis. Org. Lett. 2018, 20, $4072-4076$. [CrossRef]

78. Wang, M.; Carver, J.J.; Phelan, V.V.; Sanchez, L.M.; Garg, N.; Peng, Y.; Duy Nguyen, D.; Watrous, J.; Kapono, C.A.; Luzzatto-Knaan, T.; et al. Sharing and community curation of mass spectrometry data with global natural products social molecular networking. Nat. Publ. Gr. 2016, 34, 828-837. [CrossRef]

79. Hamed, I.; Özogul, F.; Özogul, Y.; Regenstein, J.M. Marine bioactive compounds and their health benefits: A review. Compr. Rev. Food Sci. Food Saf. 2015, 14, 446-465. [CrossRef]

80. Ahn, J.H.; Woo, J.H.; Rho, J.R.; Choi, J.H. Anticancer activity of gukulenin a isolated from the marine sponge Phorbas gukhulensis in vitro and in vivo. Mar. Drugs 2019, 17, 126. [CrossRef]

81. Xiao, Q.; Young, K.; Zakarian, A. Total synthesis and structural revision of (+)-Muironolide A. J. Am. Chem. Soc. 2015, 137, 5907-5910. [CrossRef]

82. Seo, Y.J.; Lee, K.T.; Rho, J.R.; Choi, J.H. Phorbaketal A, isolated from the marine sponge Phorbas sp., exerts its anti-inflammatory effects via NF-KB inhibition and heme oxygenase-1 activation in lipopolysaccharide-stimulated macrophages. Mar. Drugs 2015, 13, 7005-7019. [CrossRef] [PubMed]

83. Byun, M.R.; Lee, C.H.; Hwang, J.H.; Kim, A.R.; Moon, S.A.; Sung, M.K.; Roh, J.-R.; Hwang, E.S.; Hong, J.-H. Phorbaketal A inhibits adipogenic differentiation through the suppression of PPAR $\gamma$-mediated gene transcription by TAZ. Eur. J. Pharmacol. 2013, 718, 181-187. [CrossRef] [PubMed]

84. Byun, M.R.; Kim, A.R.; Hwang, J.H.; Sung, M.K.; Lee, Y.K.; Hwang, B.S.; Rho, J.R.; Hwang, E.S.; Hong, J.H. Phorbaketal A stimulates osteoblast differentiation through TAZ mediated Runx2 activation. FEBS Lett. 2012, 586, 1086-1092. [CrossRef] [PubMed]

85. Angulo-Preckler, C.; San Miguel, O.; García-Aljaro, C.; Avila, C. Antibacterial defenses and palatability of shallow-water Antarctic sponges. Hydrobiologia 2018, 806, 123-138. [CrossRef]

86. Lee, S.H.; Jeon, J.E.; Ahn, C.H.; Chung, S.C.; Shin, J.; Oh, K.B. Inhibition of yeast-to-hypha transition in Candida albicans by phorbasin H isolated from Phorbas sp. Appl. Microbiol. Biotechnol. 2013, 97, 3141-3148. [CrossRef]

87. Lee, H.Y.; Jang, E.J.; Bae, S.Y.; Jeon, J.E.; Park, H.J.; Shin, J.; Lee, S.K. Anti-melanogenic activity of gagunin D, a highly oxygenated diterpenoid from the marine sponge Phorbas sp., via modulating tyrosinase expression and degradation. Mar. Drugs 2016, 14, 212. [CrossRef] [PubMed]

88. Vijayan, R.; Subbarao, N.; Manoharan, N. Discovery of marine sponge compound as promising inhibitor for Macrophage Infectivity Potentiator (Mip) protein against Chlamydia pneumoniae. Int. J. Biosci. Biochem. Bioinform. 2015, 5, 202-210. [CrossRef]

89. Costantini, S.; Guerriero, E.; Teta, R.; Capone, F.; Caso, A.; Sorice, A.; Romano, G.; Ianora, A.; Ruocco, N.; Budillon, A.; et al. Evaluating the effects of an organic extract from the mediterranean sponge Geodia cydonium on human breast cancer cell lines. Int. J. Mol. Sci. 2017, 18, 2112. [CrossRef]

90. Teta, R.; Della Sala, G.; Esposito, G.; Via, C.W.; Mazzoccoli, C.; Piccoli, C.; Bertin, M.J.; Costantino, V.; Mangoni, A. A joint molecular networking study of a: Smenospongia sponge and a cyanobacterial bloom revealed new antiproliferative chlorinated polyketides. Org. Chem. Front. 2019, 6, 1762-1774. [CrossRef] 